\title{
Essay
}

\section{Integrating Remorse and Apology into \\ Criminal Procedure}

\author{
Stephanos Bibas ${ }^{\dagger}$ and Richard A. Bierschbach ${ }^{\dagger \dagger}$
}

\author{
CONTENTS
}

INTRODUCTION.

I. REMORSE, APOLOGY, AND CURRENT CRIMINAL JUSTICE 92

A. The Individual Badness Model .................................................. 92

B. Remorse and Apology in Criminal Procedure ............................... 95

C. Remorse and Apology in the Literature .................................... 101.

II. THE BROADER VALUE OF REMORSE AND APOLOGY ........................ 104

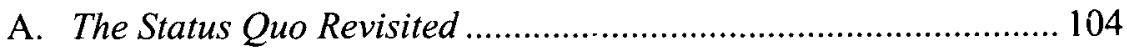

B. The Broader Value of Remorse and Apology.............................. 109

1. Crime as a Relational Concept.............................................. 109

2. Remorse and Apology as Relational Concepts..................... 112

3. Lessons from Noncriminal Contexts: Civil Mediation ........... 118

$\dagger$ Associate Professor, University of lowa College of Law; former Assistant United States Attorney, United States Attorney's Office for the Southern District of New York. E-mail: bibas@philo.org. B.A. Columbia; B.A., M.A. Oxford; J.D. Yale.

†† Visiting Assistant Professor, Benjamin N. Cardozo School of Law, Yeshiva University. Email: bierschb@yu.edu. B.A., J.D. University of Michigan. Thanks to David Baldus, Rachel Barkow, Randy Bezanson, George Fletcher, David Franklin, Carolyn Frantz, Steve Garvey, Kyron Huigens, Catherine Sharkey, Peter Westen, and participants in faculty workshops at Benjamin N. Cardozo and University of Iowa Law Schools for their advice and commentary on earlier drafts, and to Jeffrey Andersen, Joseph Baranello, Bryan Bennett, Keith Kasten, Indira Khan, Svetlana Mirkis, and Ted Moore for able research assistance. 
C. The Practical Import of the Relational Perspective

III. IMPLEMENTING REMORSE AND APOLOGY

A. At the Beginning of the Criminal Process................................... 128

B. Victim-Offender Mediation and Similar Mechanisms ................ 130

C. Cooperating Witnesses............................................................. 134

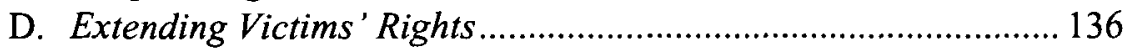

E. Fixing Plea Procedures ........................................................... 140

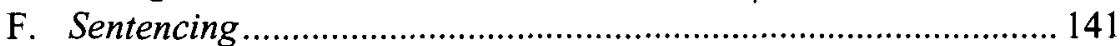

G. Costs and Difficulties of Implementing Remorse and Apology.... 145

CONCLUSION 


\section{INTRODUCTION}

Remorse and apology are powerful forces in everyday life. Parents make their children apologize for everyday wrongs. "I'm sorry" is a common expression, and confession and forgiveness loom large in both religious rituals and secular reconciliation. When a politician does something wrong, "a simple, direct apology is often the one thing voters most want to hear." Thus, political leaders either apologize for everything from sexual indiscretions to historic injustices or else are criticized for not apologizing enough. ${ }^{2}$ People value remorse and apology because they heal psychic wounds, teach lessons, and reconcile damaged relationships.

Remorse and apology should also loom large in the criminal arena, where victims' wounds are the greatest and need the most healing. Victims and victimized communities have long viewed remorse and apology as essential elements of justice for crimes. For example, one victim who was sexually abused by a priest demanded expressions of remorse to help him find closure and heal. ${ }^{3}$ Like so many others, however, he had to file a civil lawsuit to seek justice and apology, as he had received none from the criminal justice system. In another case, a driver ran over a man in a hitand-run accident and left him in a coma. The driver's lawyer discouraged her from apologizing for fear of prejudicing her criminal case. Eight months after the accident, the driver said she was sorry for what had happened but did not acknowledge her role. The brief, belated non-apology left the victim's family dissatisfied and frustrated. ${ }^{4}$

When criminal justice does produce remorse, the effects can be profound. When victims' relatives confronted serial killer Gary Leon

1. David Firestone, Being a Politician Means Never Having To Say You're Sorry, N.Y. TIMES, Aug. 23, 1998, $\S 4$ (Week in Review), at 2.

2. Firestone quotes apologies by a former South Korean president for abuse of power ("It is more than unbearable for me to face you and make this confession of my shameful deeds, and I deeply apologize.... The scar will be forever with me in my heart for the people who have suffered, and for this I feel more regret than I can express.") and former President George H.W. Bush ("The internment of Americans of Japanese ancestry was a great injustice ... and it will never be repeated."). Id. He also notes that President "Clinton's inability to use any form of the word 'apologize' last week in his speech to the nation about his affair with Monica S. Lewinsky was the aspect of his remarks that was most criticized the next day." Id.

3. Michael S. Rosenwald, Alleged Victim Demands Apology from Monsignor, Boston GLOBE, Apr. 30, 2002, at A16 (noting that victim "said he will feel closure-and the Catholic Church will begin to heal-only when [the alleged abuser] and other accused clergy publicly take full responsibility for their actions and apologize").

4. Robin Topping, Attorneys Balance 'Safe' with 'Sorry,' NEwSDAY (N.Y.), Feb. 4, 2004, at A22 (noting that while victims "first and foremost" want apologies, "the [defense] lawyer's position always is to not make admissions of any kind" "for fear of hurting the criminal case, or at most to issue a non-apology "saying you are sorry that this tragedy occurred, which is not an admission,"” quoting a sociology professor and two prominent criminal defense attorneys, respectively). 
Ridgway at sentencing, they sobbed and poured out their anger and loss. The judge expressed the community's moral condemnation and spoke of bringing peace and closure. In return, Ridgway expressed sorrow and apologized, and at least one victim's relative forgave him and expressed a feeling of peace. ${ }^{5}$ Ridgway's remorse and apology were no substitute for punishment, but they helped to begin the healing process.

Surprisingly, however, remorse and apology play little role in criminal procedure. Our criminal justice system works as a speedy assembly line: It plea bargains cases efficiently and maximizes punishment for the limited resources available. This assembly line leaves little room for remorse and apology. At most, they creep in interstitially, as indicators that individual defendants are less bad and so need less deterrence, incapacitation, or retribution. We will call this defendant-centered approach to remorse and apology the "individual badness model." As we show in Part I, this approach dominates existing judicial decisions, such as cases applying section 3E1.1 of the Federal Sentencing Guidelines, ${ }^{6}$ as well as the academic literature. ${ }^{7}$

We dispute this conventional approach. Remorse and apology could do much more than serve as gauges of an individual defendant's need for punishment. Remorse and apology are fundamentally about social interactions and relationships. Serious wrongdoers sometimes apologize not only to the direct victim, but also to everyone who suffered indirect harm, such as members of the victim's family and community. Victims, in return, can air their sorrows while expressing forgiveness to the wrongdoer.

5. Gene Johnson, 'Green River Killer' Apologizes, Is Sentenced to 48 Life Terms, BostoN GLOBE, Dec. 19, 2003, at A12; see also, e.g., John Donnelly, Appealing for Forgiveness: ExConvicts Reach Out to Victims in South Africa, BosTON GLOBE, Dec. 31, 2003, at Al; Oliver Duff, Sidebar, in Kathy Marks \& Paul Peachey, Traditional Maori Ways Translate to a New Style of Justice in Britain, INDEPENDENT (London), Aug. 25, 2003, at 3 ("[The offender] . . . credits [a face to face meeting with the victim] with saving him from further trouble. "It was oniy when I shook hands with him that I really felt sorry for what I'd done. . . [T] [That was a big deal for us."'); Grant Wahl \& L. Jon Wertheim, A Rite Gone Terribly Wrong, SPORTS IlluSTRATED, Dec. 22, 2003 , at 68,77 ("[T] he had done to the [hazing victims]. 'I know it sounds silly,' says Kelly, the attorney for two of the victims, "but [his apology] meant something to the families."') (last alteration in original).

6. See U.S. SENTENCING GUIDELINES MANUAL § 3E1.1, cmt. n.3 (2003) (providing two- or three-level sentence reduction for acceptance of responsibility).

7. Up through the mid-1990s, the literature contained almost no substantial discussions of the role of remorse and apology in the criminal justice system on any but the most abstract level. Michael O'Hear's 1997 article marked the first serious attempt to examine how on-the-ground rules and practices in criminal law treat expressions of remorse and contrition in administering criminal punishment. See Michael M. O'Hear, Remorse, Cooperation, and "Acceptance of Responsibility": The Structure, Implementation, and Reform of Section 3E1.1 of the Federal Sentencing Guidelines, 91 NW. U. L. REV. 1507 (1997). Since that time, remorse, apology, and related concepts have attracted the attention of prominent scholars in the field. See infra Section I.C. The last half-decade has also witnessed an explosion of writing on the topics in the civil law arena. See, e.g., sources cited infra Subsection II.B.3. 
Ideally, this interactive process teaches moral lessons, brings catharsis, and reconciles and heals offenders, victims, and society. We will call this multiactor perspective the "relational approach" to distinguish it from the defendant-focused individual badness model. ${ }^{8}$

The individualism of the badness model parallels the criminal law's individualistic approach to punishment. Traditionally, criminal law has focused on deterring, incapacitating, rehabilitating, and inflicting retribution on individual defendants. This focus has come at the expense of the broader social dimension of punishment. Recently, academics have begun theorizing about incorporating moral education, healing, reconciliation, and victim vindication more directly into criminal law. ${ }^{9}$ Unfortunately, criminal procedure is artificially divorced from these substantive values of the criminal law, focusing instead on accuracy, efficiency, and procedural fairness. ${ }^{10}$ Thus, criminal procedure leaves little room for apology and remorse. What room exists is artificial, such as the more or less automatic sentencing discount for guilty pleas in federal court regardless of how contrite a defendant is. ${ }^{11}$

In short, criminal procedure neglects the power of remorse and apology. To remedy this neglect, we must focus not just on the individual defendant's supposed badness, but also on the social practices and norms of remorse and apology. Remorse and apology are useful as more than mere

8. In practice, the distinction is not always a neat dichotomy. For example, sentencers who focus on the remorse and apology of individual offenders in meting out punishment also care about the effects of these expressions on victims and the community. Likewise, victims and communities who value remorse and apology for their cathartic and expressive power also frequently see them as relevant to determining sentences. The two approaches we identify shade into each other, but this does nothing to undermine our central claim that the individual badness model has dominated the criminal justice system's stance toward remorse and apology so far.

Our relational model also contains aspects that the word "relational" does not fully capture; the model seeks to restore victims, to reconcile victims to offenders, to remediate harm, and to reintegrate offenders into society. For the sake of brevity, however, we use the single but inexact word "relational" to describe our model. In some fields, such as torts, "relational" implies a focus on only the plaintiff and defendant. Some might understand this focus to exciude the web of social relationships torm by the defendant's conduct. When we use the word "relational," we do not mean to limit our focus to the wrongdoer and the victim. While remorse and apology require at least these two parties, ideally they involve everyone affected directly or indirectly by the wrong.

9. See, e.g., Stephen P. Garvey, Can Shaming Punishments Educate?, 65 U. CHI. L. REV. 733, 762-75 (1998) [hereinafter Garvey, Shaming Punishments] (discussing the role of moral education in punishment); Stephen P. Garvey, Punishment as Atonement, 46 UCLA L. REV. 1801, 1804-29 (1999) [hereinafter Garvey, Punishment as Atonement] (discussing how punishment should lead to atonement, reconciliation, and healing); Dan M. Kahan, What Do Alternative Sanctions Mean?, 63 U. CHI. L. REV. 591, 594-601 (1996) (stressing the importance of punishment as a way to express condemnation).

10. Stephanos Bibas, Harmonizing Substantive-Criminal-Law Values and Criminal Procedire: The Case of Alford and Nolo Contendere Pleas, 88 CORNELL L. REV. 1361, 1362 (2003).

11. See O'Hear, supra note 7 , at $1534-40$ (describing how judges in most federal districts tend to award acceptance-of-responsibility discounts to defendants who plead guilty and deny them to defendants who stand trial). 
metrics for punishment. Apology, we argue, is a powerful ritual for offenders, victims, and communities, one that criminal procedure could facilitate by encouraging offenders to interact face to face with their victims. The focus would broaden beyond the individual offender's badness to constructive measures to heal offenders, victims, and communities. Remorse and apology would teach offenders lessons, vindicate victims, and encourage communities to welcome wrongdoers back into the fold. Of course, not all offenders or victims would be able and willing to take part. But the available empirical and anecdotal evidence shows that many would and that those who did might reap dramatic benefits. Thus, criminal procedure would serve the criminal law's substantive values instead of undercutting them.

Before continuing, we should explain briefly what we mean by expressions of remorse and apology. We use these terms broadly and generally, as the law does, to include offenders' expressions of contrition, sorrow, shame, repentance, and the like. While these other expressions are helpful, the core of an apology is "an expression of sorrow and regret." The offender should both feel sorry and express this sorrow, ${ }^{13}$ although, as Section III.F explains, even half-hearted or insincere apologies are better than nothing. At a minimum, apology is at least a dyadic relation and interaction, requiring an expression of sorrow by the offender to the victim or victims. ${ }^{14}$ Subsection II.B.2 delves further into the psychological mechanisms that make remorse and apology powerful tools for healing relationships. Our aim is to show how the criminal justice system's ambivalent stance toward this cluster of practices obscures and undermines the key values that they serve.

In Part I, we explore the role that remorse and apology currently play in criminal law. As Section I.A explains, criminal law views remorse and apology through the lens of the individual badness model, primarily as proxies for how bad an individual defendant is and how much punishment he or she needs. Section I.B shows that criminal procedure emphasizes the procedural values of fairness, efficiency, and accuracy at the expense of the substantive values espoused by the criminal law. Section I.C notes that, while academics have recently shown interest in remorse and apology, most try to fit these values into the individual badness model. In addition, few discuss how to implement these values through real-world institutions, policies, and procedures.

12. Nicholas Tavuchis, Mea CulPa 23 (1991).

13. Id. at 31,36 .

14. Lee Taft, Apology Subverted: The Commodification of Apology, 109 YALE L.J. 1135, 1139 (2000) (citing TAVUCHIS, supra note 12, at 46). 
Part II explains why we should value remorse and apology more broadly. Section II.A discusses why remorse and apology are poor proxies - both practically and theoretically - for individual badness and the need for deterrence and retribution. While deterrence and retribution are legitimate guideposts for sentencing, they do not exhaust the roles of remorse and apology. Section II.B notes that remorse and apology are valuable for broader reasons than the individual badness model recognizes. Crime is more than individual wrongdoing; it is relational. Crime creates moral imbalances and sends false moral messages. Remorse and apology can help right the moral balance, annul false moral messages by vindicating victims, and reconcile offenders to their victims and communities. Section II.C ties these insights together. Remorse and apology are not substitutes for punishment in most cases, as the restorative justice movement mistakenly contends. Nor are they simply cheap, cruel ways of inflicting humiliation, as advocates of shaming punishments imply. Rather, they should be integral to criminal justice, supplementing but not supplanting deterrence and retribution. Remorse and apology neither displace nor justify punishment, but, as functions of punishment, they can better complement and serve its goals.

Part III suggests how the law could translate these ideals into real-world procedures. Before and after arrest, and before and after charging decisions, offenders should have sufficient opportunities to resolve lower-level crimes informally by apologizing and making amends. From arrest through imprisonment, offenders and victims should have plenty of chances for court-supervised mediation. Prosecutors could make more use of remorse and apology to encourage offenders to cooperate with law enforcement and tell the truth. Victims and the community should have greater opportunities to participate at all stages in the criminal process, including mediation, restitution, plea, and trial. Plea and sentencing procedures should include explicit roles for remorse and apology.

Part III ends with some caveats. These measures will not work for all crimes and are hardest to implement for victimless crimes or those with many victims. In addition, not all offenders or victims will be willing to take part, some apologies will be insincere, and some offenders will lack the mental capacity for remorse. ${ }^{15}$ Our proposals may seem idealistic to veterans of our efficient punishment assembly line. It will take time and effort to adapt the system to better focus on healing and reconciling victims and offenders. But when both sides are open to it-and, surprisingly often, they are-offenders, victims, and communities all stand to benefit.

15. See infra Section III.F (discussing insincere apologies); infra Section III.G (discussing caveats). 


\section{REMORSE, APOLOGY, AND CURRENT CRIMINAL JUSTICE}

The criminal justice system is deeply ambivalent about remorse and apology. According to Austin Sarat, perhaps no expressions are more "universally welcomed within, and by, the legal system." 16 Judges, sentencing juries, the news media, and the public overwhelmingly weigh remorse heavily in disposing of criminal cases and in assessing offenders as persons. At the same time, criminal procedure does little to encourage or even allow meaningful apologies and expressions of remorse from offenders to their victims and the community. Remorse and apology often lurk in the interstices, appearing only as pro forma statements from defendants to judges at sentencing. Likewise, expressions of remorse and apology have received minor and incomplete treatment in the criminal law literature. Commentators tend to focus on practical and pragmatic issues raised by the current place of remorse and apology in the criminal justice system. They do not explore how remorse and apology could play a larger role in on-the-ground practices and institutions.

In Sections A and B, we examine the criminal law's uneasy relationship with expressions of remorse and apology. Section A explains that the substantive criminal law considers such expressions important mainly for what they are believed to say about an individual offender's criminal disposition. Criminal procedure, however, does not reflect this emphasis, as we argue in Section B. Section C explores the place of remorse and apology in the academic literature.

\section{A. The Individual Badness Model}

The criminal law is replete with evaluative judgments based on apologies and expressions of remorse. Newspapers routinely report stories of victims who demand apologies, criminal defense attorneys who note their clients' deep remorse, and judges who cite defendants' lack of remorse when imposing harsh sentences. ${ }^{17}$

16. Austin Sarat, Remorse, Responsibility, and Criminal Punishment: An Analysis of Popular Culture, in ThE PASSIONS OF LAw 168, 168 (Susan A. Bandes ed., 1999); see also Scott E. Sundby, The Capital Jury and Absolution: The Intersection of Trial Strategy, Remorse, and the Death Penalty, 83 CORNELL L. REv. 1557, 1557 (1998) ("Few ideas reverberate at the core of the human psyche as strongly as that of atonement.").

17. Recent high-profile examples include Sister Helen Prejean's account of Patrick Sonnier's execution in the popular book Dead Man Walking, and the August 2003 parole of former 1960s radical and member of the Weathermen Kathy Boudin. See HELEN PREJEAN, DEAD MAN WALKING 244 (1993) (writing that a victim's father attended the execution of his son's murderer because he wanted to hear an apology, not to savor revenge); Charles Lane \& Christine Haughney, Former Militant Is Granted Parole; Upcoming Release Angers Victim's Family. 
In many of these cases, the presence or absence of remorse, contrition, or apology can greatly help or hurt defendants. In federal court, for example, judges reduce sentences by two or three levels for defendants who express contrition or remorse. ${ }^{18}$ At the high end of the Federal Sentencing Guidelines, this reduction can subtract years from a defendant's sentence. ${ }^{19}$ The effect is just as stark at the state level. ${ }^{20}$ In capital sentencing, according to one study, a defendant's perceived remorse can significantly reduce the likelihood that a jury will impose the death penalty, especially for less vicious murders. ${ }^{21}$

Others, WASH. POST, Aug. 21, 2003, at A2 ("At Bedford Hills Correctional Facility, Boudin expressed remorse ....").

18. U.S. SENTENCING Guidelines MANUAL $\S 3 E 1.1$, cmt. n.3 (2003); see United States v. Fagan, 162 F.3d 1280, 1284 (10th Cir. 1998) ("Several circuits have specifically held that a moral element is implicit in acceptance of responsibility and is satisfied by the defendant's expression of contrition and remorse.") (citing cases); United States v. Hammick, 36 F.3d 594, 600 (7th Cir. 1994) (observing that "a fundamental principle underlying the acceptance of responsibility reduction" is "that in the absence of evidence of sincere remorse or contrition for one's crimes, a guilty plea entered for the apparent purpose of obtaining a lighter sentence does not entitle a defendant to a reduction for acceptance of responsibility"); O'Hear, supra note 7, at 1526, 1524$26 \& \mathrm{nn} .72-77$ (noting that almost all appellate courts treat section $3 \mathrm{E} 1.1$ as "fundamentally about remorse or contrition," but that in many but not all federal districts, judges automatically award acceptance-of-responsibility discounts to all defendants who plead guilty). While recent amendments to sentencing law now require a prosecutorial motion for the third level of reduction, see Prosecutorial Remedies and Other Tools To End the Exploitation of Children Today (PROTECT) Act of 2003, Pub. L. No. 108-21, § 401(g), 117 Stat. 650, 671, there is little reason to think that these amendments will strengthen the tenuous tie between "acceptance of responsibility" and true remorse or contrition.

19. Take, for example, a Category I offender whose offense level drops from thirty-seven to thirty-four after he receives a three-point reduction for acceptance of responsibility under section $3 E 1$.1. The offender's sentencing range drops from 210 to 262 months down to 151 to 188 months, a reduction of five to six years. See U.S. SENTENCING GUIDELINES MANUAL $\$ 3 E 1.1$; id. ch. 5, pt. A. As a general matter, a two- or three-level reduction in a defendant's offense level usually reduces his sentencing range by about thirty-five percent. See id;; Julie R. O'Sullivan, In Defense of the U.S. Sentencing Guidelines' Modified Real-Offense System, 91 NW. U. L. REV. 1342,1415 \& n.274 (1997) (collecting sources).

20. See, e.g., State v. Hinson, 855 So. 2d 119, $121-22$ (Fla. Dist. Ct. App. 2003); State v. Farnham, 479 A.2d 887, $891-93$ (Me. 1984); Saenz v. State, 620 A.2d 401, 403-07 (Md. Ct. Spec. App. 1993).

21. See Theodore Eisenberg et al., But Was He Sorry? The Role of Remorse in Capital Sentencing, 83 CORNELL L. REV. 1599, 1631-36 \& tbls.9-10 (1998) (measuring capital jurors' beliefs and their correlation with sentencing outcomes in a multivariate empirical study); see also Riggins v. Nevada, 504 U.S. 127, 144 (1992) (Kennedy, J., concurring in the judgment) ("In a capital sentencing proceeding, assessments of character and remorse may carry great weight and, perhaps, be determinative of whether the offender lives or dies."); Eisenberg et al., supra, at 163233 (finding that the "the difference ... between jurors' beliefs about the defendant's remorse in life cases and in death cases is highly significant" and concluding that, "[i]n short, if jurors believed that the defendant was sorry for what he had done, they tended to sentence him to life imprisonment, not death"); Stephen P. Garvey, Aggravation and Mitigation in Capital Cases: What Do Jurors Think?, 98 CoLUM. L. REV. 1538, 1559-61 (1998) (reaching same conclusion); Sundby, supra note 16, at 1560-66. As Eisenberg and his coauthors note, the presence or absence of remorse does not always exert a significant influence on capital sentencing juries. See Eisenberg et al., supra, at 1600. "[I]n highly vicious cases," they found, "a defendant's remorse may not be able to save him. But in lower viciousness cases..., remorse may make all the 
Seemingly remorseless acts by children or adolescents can affect whether they are tried as juveniles or as adults. ${ }^{22}$ Parole boards take remorse into account in making release decisions. ${ }^{23}$ Contrition and apologies influence prosecutors' decisions, including decisions not to charge, to accept proposed pleas, to enter into cooperation agreements, and to recommend favorable sentences. ${ }^{24}$

Why does the criminal law accord so much weight to these expressions? In the eyes of judges, they indicate that an offender is not "lost," that he has some self-transformative capacity that justifies (or requires) a lesser punishment. To be sure, the language of judicial opinions does not always express this sentiment directly. Some judges say that the remorseful offender has a better character than does the unremorseful one. ${ }^{25}$ Others say that he is more likely to be rehabilitated, ${ }^{26}$ or that he is less

difference." Id. at 1636. For a good summary of how remorse can fit into a state's statutory scheme in capital cases, see id. at 1604-07.

22. See Martha Grace Duncan, "So Young and So Untender': Remorseless Children and the Expectations of the Law, 102 COLUM. L. REV. 1469, 1471 (2002) ("In many jurisdictions, the presence of contrition is a legitimate argument for retaining juvenile jurisdiction, whereas its absence militates in favor of 'binding the child over' to the criminal system."); Christopher Slobogin, Treating Kids Right: Deconstructing and Reconstructing the Amenability to Treatment Concept, 10 J. CONTEMP. LEGAL IsSUES 299, 310-11 (1999) (citing relevant cases and summarizing the ways that remorse or its absence can bear on the criteria for transfer).

23. See, e.g., In re Smith, No. B157419, 2003 Cal. App. LEXIS 824, at *33-35 (Ct. App. June 5, 2003); Silmon v. Travis, 741 N.E.2d 501, 505-06 (N.Y. 2000).

24. See Michael A. Simons, Retribution for Rats: Cooperation, Punishment, and Atonement, 56 VAND. L. REV. 1, 43-44, 49-50 (2003) (observing that remorseful, apologetic, and generally repentant cooperators are more valuable to prosecutors than are unrepentant cooperators); Deena Winter, Short Sentence Angers Some, BISMARCK (N.D.) TRIB., Apr. 1, 2000, at Al (reporting prosecutor's recommendation of a favorable sentence for defendant who "showed remorse, accepted responsibility" and offered a "lengthy apology" at sentencing). For some lower-level nonviolent crimes involving first-time offenders, the prosecutor may enter into a diversion agreement with the offender whereby criminal charges are continued and eventually dropped after the offender fulfills the requirements in the diversion agreement. Often, one important requirement of such agreements is that the offender apologize to his victim and members of his community for his wrongdoing. See, e.g., Joint Motion To Continue-Diversion Agreement 9 9, New Hampshire v. Doe (Sept. 27, 2001) (docket number and court name redacted) (on file with authors) (requiring the defendant to "submit to the Court... and to the Office of the County Attorney an essay ... which will set out an apology to the defendant's parents, an apology to [the defendant's school], and an apology to the County Attorney as a representative of the ... Police Department and the New Hampshire community").

25. See, e.g., Cloum v. State, 779 N.E.2d 84, 90 \& n.3 (Ind. Ct. App. 2002) (holding that trial judge erred in failing to consider defendant's "tru[e] remorse" and other evidence of "his general good character," coupled with his decision to plead guilty, as a mitigating circumstance at sentencing).

26. See, e.g., United States v. Blake, 89 F. Supp. 2d 328, 352 (E.D.N.Y. 2000) ("[The defendant] has repented by recognizing her guilt. She is remorseful over what she has done. She has also sought to apologize for her crime both to society at large and to [the victim] in particular ... This reflection and introspection is an aspect of her rehabilitation."). 
hardened, ${ }^{27}$ or simply that he deserves less punishment. ${ }^{28}$ Whatever the precise language, the judges' point is that the remorseful offender is in some way changed, or likely to change. Judge Posner expressed this idea in United States v. Beserra: "A person who is conscious of having done wrong, and who feels genuine remorse for his wrong, . . . is on the way to developing those internal checks that would keep many people from committing crimes even if the expected costs of criminal punishment were lower than they are."29

This notion, which we call the individual badness model, dominates the criminal law's current stance toward expressions of apology and remorse. This model, coupled with criminal law's divorce of substance from procedure and its neglect of relational concepts, has obscured how remorse and apology can do much more to heal, reconcile, and reintegrate. The individual badness model has overshadowed this side of remorse and apology.

\section{B. Remorse and Apology in Criminal Procedure}

While remorse and apology are central to judgments about offenders and are important to victims and the public, day-to-day criminal justice makes very little room for them. Society deals with street crime through command-and-control strategies that consist largely of assembly-line justice. Mandatory minimum sentences and harsh recidivist laws govern punishment for many street crimes. ${ }^{30}$ The focus is on achieving as just an outcome as possible for each offender with maximum efficiency; procedures speed cases through to a mathematically correct disposition. ${ }^{31}$

27. See, e.g., 3 Get Youth Detention in Rape of Retarded Teen, CHI. TRIB., Apr. 24, 1993, § 1, at 10 (quoting sentencing judge's observation, upon defendants' apologies, that "they are not hardened criminals" and "not without redeeming value").

28. See, e.g., State v. Brown, 1986 WL 13263, at *2 (Tenn. Crim. App. Nov. 26, 1986) (docket number missing) (reducing defendant's sentence from two ten-year terms to two threeyear terms to ensure that it was "no greater than that deserved for the offense" in light of, among other things, "the fact that the defendant expressed remorse over the incident" (internal quotation marks omitted)).

29. 967 F.2d 254, 256 (7th Cir. 1992) (Posner, J.).

30. See, e.g., 16B AM. JUR. 2D Constitutional Law $\S 656$ (1998) (surveying recidivist statutes); BurEau of Justice STATISTICS, DeP'T OF JUSTICE, SOURCEBoOK OF CRIMINAL JUSTICE STATISTICS $§ 5$ (1998) (reporting sentencing data for federal and state courts); Darryl K. Brown, Street Crime, Corporate Crime, and the Contingency of Criminal Liability, 149 U. PA. L. REV. 1295, 1314-15 (2001) (noting that "[t]he number of people in jails and prisons exceeded two million for the first time in 1999, average sentence lengths have increased, and offenders are more likely to have parole revoked for minor violations" and observing generally that today's "punitive prosecutorial policies ... demonstrate a commitment to harsh criminal approaches").

31. See, e.g., Fed. R. CRIM. P. 2; Herbert L. PACKer, The Limits of the Criminal SANCTION 153, 159, 163-64 (1968); 1 Charles Alan Wright, Federal PraCtice and PROCEDURE: CRIMINAL $\S 31$ (3d ed. 2000) (discussing general purpose of Federal Rules of Criminal Procedure); Douglas Evan Beloof, The Third Model of Criminal Process: The Victim 
Efficiency is valuable, but it comes at a price. ${ }^{32}$ This emphasis on efficiency exemplifies a larger trend. Criminal procedure has come to focus on serving procedural values such as fairness, efficiency, and accuracy to the exclusion of incorporating substantive goals into the structure of procedural mechanisms. ${ }^{33}$ In the words of William Stuntz, criminal procedure today "is, basically, a subset of constitutional law," leading to an artificial separation between criminal procedure and the substantive values at which the law aims. ${ }^{34}$

This divorce of substantive values from procedure is apparent in criminal procedure's treatment of remorse and apology. In theory, criminal law purports to concern itself with discerning and encouraging expressions of remorse and apology. ${ }^{35}$ But "in practice, far more attention is devoted to the prevention and punishment of crime than to ways in which criminals might be encouraged to repent and resume normal lives." ${ }^{.36}$ As a consequence, for all of their resonance with criminal law's substantive values, remorse and apology have little room to flourish in criminal procedure. In some instances, direct procedural barriers obstruct apology and remorse; in other cases, procedure fails to ameliorate practical and contextual barriers. When remorse and apology do appear, they do so in spite of the criminal process, not because of it.

Consider a typical offender - a vandal, maybe, or a low-level drug dealer, or a thief--in a typical small criminal case. From the time of arrest to sentencing, criminal procedure pays little heed to his expressions of

Participation Model, 1999 UTAH L. REV. 289, 292-93 (emphasizing that current models of the criminal process focus on "the efficient suppression of crime," where "[e]fficiency is the capacity to process criminal offenders rapidly" in "a factory that has to devote a substantial part of its input to quality control" (internal quotation marks omitted)). Federal and state sentencing guidelines exemplify this mathematical trend. See Simons, supra note 24, at 9-10.

32 . Conversely, a system that allowed more room for remorse and apology would probably be less speedy and efficient. Each value requires tradeoffs of time and money. For example, the system works much faster when the repeat players do not have to worry about victims' and defendants' desires and interests. But because victims, defendants, and communities have personal stakes in the outcomes, unlike the repeat players, their interests and desires should carry weight as well.

33. See Bibas, supra note 10 , at $1362-64,1401$.

34. William J. Stuntz, The Uneasy Relationship Between Criminal Procedure and Criminal Justice, 107 YALE L.J. 1, 6 (1997) (decrying the artificial separation between criminal procedure and substantive criminal law).

35. See supra Section I.A. This point is evident in the philosophical theories of punishment that undergird the criminal law. See, e.g., R.A. DUFF, TRIALS AND PUNISHMENTS 254-62 (1986) (explaining that the punisher tries to induce contrition and repentance so that the offender will repudiate his past wrongful act and avoid committing it again); Jean Hampton, The Moral Education Theory of Punishment, in PUNISHMENT: A PHILOSOPHY \& PUBLIC AFFAIRS READER 112, 115-17, 120-21 (A. John Simmons et al. eds., 1995) (arguing that punishment teaches the offender that the crime is forbidden because it is morally and iegally wrong).

36. Robert Wuthnow, Repentance in Criminal Procedure: The Ritual Affirmation of Community, in REPENTANCE: A COMPARATIVE PERSPECTIVE 171, 172 (Amitai Etzioni \& David E. Carney eds., 1997); see also id. at 179. 
contrition. Beginning with arrest, he enters an adversarial system in which two lawyers, not the defendant and the victim, are the main actors. Often operating under staggering caseloads, the lawyers are concerned with negotiating just and speedy dispositions. ${ }^{37}$ In most cases, this means cutting deals on charges, pleas, and sentences. ${ }^{38}$ In the few cases headed toward trial, it means investigating, planning pretrial and trial strategy, and dealing with motions, trial dates, and the like. In either situation, much negotiation is informal and takes place between the two repeat players, out of the defendant's presence. ${ }^{39}$ These two players strive to balance adversarial processes, efficient and accurate outcomes, and individual rights. They do not emphasize mining the possible value of remorse, apology, or repentance. $^{40}$

Throughout this process, the defendant has little chance to interact with anyone other than his own attorney. At their first meeting, the defendant's attorney tells him to say nothing to anyone except the attorney himself. Their few later conversations overwhelmingly concern facts and legal niceties. Until it is time for the presentence report, any expressions of contrition or remorse make it only as far as the defense attorney or, on rare occasions, the prosecutor. Defense attorneys and prosecutors usually view these expressions as relevant only to the defendant's willingness to fight, plead, or perhaps cooperate. ${ }^{41}$ The genuinely remorseful offender who wishes to apologize to his victim and make amends usually has no readily available way to do so. Indeed, from the time of arrest until trial (if there is one) and sentencing, victims are almost never in sight of the offender. ${ }^{42}$

37. See, e.g., David A. Starkweather, Note, The Retributive Theory of "Just Deserts" and Victim Participation in Plea Bargaining, 67 IND. L.j. 853, 875, 874-75 (1992) (noting that prosecutors must serve conflicting goals, one of which is the "swift disposition of cases"); Stephen B. Bright, Turning Celebrated Principles into Reality, CHAMPION, Jan./Feb. 2003, at 6, 8-9 (discussing overwhelming caseloads of many criminal defense attorneys and resultant pressures to dispose of cases quickly and "on the cheap").

38. Guilty pleas resolve $94 \%$ to $95 \%$ of criminal cases, and most of these probably result from plea bargains. Stephanos Bibas, Plea Bargaining Outside the Shadow of Trial, 117 HARV. L. REV. 2463, 2466 n.9 (2004) (collecting statistics).

39. See 1 Wayne R. LaFave et al., Criminal Procedure § 1.9(f) (2d ed. 1999 \& Supp. 2004) (reviewing different types of informal interactions that take place between defense counsel and prosecutors); see also, e.g., United States v. Valencia, 826 F.2d 169, 173 (2d Cir. 1987) (recognizing importance of "informal attorney statements" for "plea negotiation [and] . . frank discussion between defense counsel and prosecutor on various topics that must be freely discussed in the interest of expediting trial preparation and the conduct of the trial").

40. To use Markus Dirk Dubber's words, "In the war on crime, offenders and victims alike are irrelevant nuisances, grains of sand in the great machine of state risk management." Markus Dirk Dubber, Policing Possession: The War on Crime and the End of Criminal Law, 91 J. CRiM. L. \& CRIMINOLOGY 829,849 (2001).

41. See Neal Kumar Katyal, Conspiracy Theory, 112 YALE L.J. 1307, 1356-57 (2003); Simons, supra note 24, at 50 n.223.

42. See Heather Strang \& Lawrence W. Sherman, Repairing the Harm: Victims and Restorative Justice, 2003 UTAH L. REv. 15, 23 (noting that "discussion of apology is redundant" 
Procedurally, apology and remorse factor in most significantly at sentencing. Even here, however, these expressions are largely pro forma. In many cases, the context of the sentencing allocution inhibits rather than facilitates meaningful remorse and apology. By the time of sentencing, criminal procedures have done little to encourage repentance, apology to victims, or coming to terms with one's guilt. Some defendants in effect plead guilty without admitting guilt by entering pleas of nolo contendere or Alford pleas. ${ }^{43}$ Others contest their charges but are found guilty after trial. For both types of defendants, cognitive dissonance and continued denials make it particularly hard to express remorse and apologize. ${ }^{44}$

Defendants who have fully admitted their guilt and pleaded guilty also face significant psychological and contextual barriers. Courtrooms are quasi-public settings, where defendants' families and close friends are often present. This setting can humiliate offenders, especially those who prize their reputations most highly (such as white-collar offenders) or who have committed highly stigmatized crimes (such as sex offenders). ${ }^{45}$ Sentencing allocutions, moreover, are tightly scheduled, hurried, vague, and often in front of a judge who did not preside over the guilty plea. ${ }^{46}$ For most defendants, this is their first real chance to apologize for their crime to victims or the community. It is no wonder that, when apologies do occur at sentencing, they often are stilted, forced, or "not enough."47 Many defendants simply read from a piece of paper. ${ }^{48}$

in light of "the dominant adversarial paradigm of the court system," which provides "no opportunity ... for a direct exchange between [victims] and their offenders"); see also, e.g., PEGGY M. TOBOLOWSKY, CRIME VICTIM RIGHTS AND REMEDIES 39 (2001) (noting that, despite expanding victim-notification rights, victims frequently are still unaware of the status of their cases). The single exception to this state of affairs is the small but growing number of cases for which victim-offender mediation is available. See infra notes 139-154 and accompanying text.

43. A nolo contendere plea admits guilt for purposes of the present case but creates no estoppel, while an Alford plea allows a defendant to plead guilty while simultaneously asserting his innocence. Federal courts and most state courts permit both kinds of pleas. See Bibas, supra note 10 , at $1370-72 \& \mathrm{nn} .44,52$ (collecting federal and state citations).

44. See Kenneth S. Bordens \& Irwin A. Horowitz, Social Psychology 221 (2d ed. 2002) (explaining that, according to cognitive-dissonance theory, persons who take positions publicly are more likely to harden their attitudes to keep them in line with those positions even when real-world events cail those positions into question); Bibas, supra note 10, at 1393-400.

45. For sources discussing the reputational sensitivity of white-collar defendants and its denial-related consequences, see, for example, PRESIDENT'S COMM'N ON LAW ENFORCEMENT \& ADMIN. OF JUSTICE, TASK FORCE REPORT: CRIME AND ITS IMPACT-AN ASSESSMENT 11 (1967); and Dan M. Kahan \& Eric A. Posner, Shaming White Collar Criminals: A Proposal for Reform of the Federal Sentencing Guidelines, 42 J.L. \& ECON. 365, 368-72 (1999). For sources discussing sex crimes, see Bibas, supra note 10 , at 1393-97 $\mathrm{nn} .156-82$.

46. See generally United States v. Williams, 23 F.3d 629, 632-33 (2d Cir. 1994) (noting that, with the parties' consent, federal district courts may delegate guilty-plea allocutions to magistrates); 5 LAFAVE ET AL., supra note $39, \S 26.4(\mathrm{~g})$, at 1231 (describing the defendant's opportunity to address the sentencing authority at allocution).

47. See Strang \& Sherman, supra note 42, at 29 ("[A] sincere expression of remorse is ... something victims almost never have the chance to hear in the courtroom."); see also, e.g., United 
Nonetheless, judges heed expressions of remorse and apology and weigh them heavily at sentencing. As Judge Leventhal put it, "There is a natural, and I believe sound, disposition to adjust sanctions when an offender admits his responsibility... . I dare say that many judges, possibly the over-whelming majority, respond in this way...."49 But even at sentencing, where criminal law actually carves out a procedural space for remorse and apology, the law focuses almost entirely on the offender. As with presentencing, context, practice, and procedure reflect this fact. We mentioned that allocution is often the first opportunity a defendant has to apologize to victims of his crime. All too often, however, this opportunity is more theoretical than real. Despite recent and dramatic increases in victims' rights, victims play minimal roles at sentencing. ${ }^{50}$ Allocution occurs between the defendant and the sentencer. ${ }^{51}$ In many instances, victims are absent from the courtroom; ${ }^{52}$ when they are present, defendants do not face them. Even for defendants who are genuinely remorseful and wish to apologize to their victims, the colloquy is between the defendant and the judge. Victims usually sit with the public behind the defendant while the judge evaluates the defendant's words and demeanor. ${ }^{53}$ At most, they read

States v. Purchess, 107 F.3d 1261, 1269 (7th Cir. 1997) (affirming district court's denial of sentence reduction on the ground that defendant's "one-sentence apology" was insufficient evidence of genuine remorse or contrition); Gregory D. Kesich, Suspect Sentenced for Murder of Friend, PORTLAND (Me.) Press HERALD, Nov. 6, 2003, at IB (noting that victim disregarded defendant's apology as insufficient); Monte Morin, Man Gets 8 Years in Charity Scheme, L.A. TIMES, July 25, 2002, at B2 (describing how prosecutors rejected defendant's open-court apology as insincere).

48. See, e.g., John P. Martin, Barber Told To Repay \$57,000-Treffinger Friend Apologizes to Judge for Clipping the County, STAR-LEDGER (Newark, N.J.), Oct. 23, 2003, at 13 (describing defendant's reading apology from a single piece of paper at his sentencing for embezzlement).

49. Scott v. United States, 419 F.2d 264, 282 (D.C. Cir. 1969); see STANTON WhEELER ET al., SitTing In Judgment: The Sentencing of White-Collar Criminals 115 (1988) (interviewing judges in pre-Guidelines study of sentencing of white-collar offenders and finding that "it is important for many judges that defendants recognize the gravity of their offense, accept the blame for their misdeeds, and express remorse or contrition for them"); supra notes 19-29 and accompanying text.

50. See, e.g., TOBOLOWSKY, supra note 42 , at $81-86,92-96$ (outlining contours of victims' rights to be heard at sentencing, in jurisdictions in which they exist, as involving only rights to speak and present information to the sentencing authority); see also Strang \& Sherman, supra note 42 , at 22 ("In general, victimology literature makes little mention of victims' desire for apologies from their offenders.").

51. As one leading treatise puts it, allocution is an opportunity for the defendant "to get across his side of the story to the sentencer" by "personally address[ing] the sentencer." 5 LAFAVE ET AL. supra note $39, \S 26.4(\mathrm{~g})$, at 774 (emphasis added).

52. See TOBOLOWSKY, supra note 42 , at $96-98$ (reviewing various studies suggesting that, as a general matter, a significant majority of felony victims are not present at sentencing).

53. Indeed, to apologize to his victim directly, a defendant in most cases would have to turn his back on the sentencing judge. Darrell L. Brooks did just that at his high-profile sentencing for the arson of a Baltimore rowhouse resulting in the death of two parents and their five children. See Gail Gibson \& Laurie Willis, Tears and Remorse Precede Life Term in Dawson Deaths; Arsonist, Victims' Family Tell Judge of Their Pain, BALT. SUN, Aug. 28, 2003, at 1 A (describing how Brooks "apologized to [Judge] Garbis for turning his back on the judge but said his comments 
brief victim-impact statements or, more commonly, submit written statements before sentencing, which judges rarely read aloud. ${ }^{54}$ There is no victim-offender dialogue and no opportunity for face-to-face apology or expressions of contrition.

Defendants likewise have few opportunities to express sorrow and apologize to community representatives. The paradigmatic symbol of the community in the criminal law-a jury of the defendant's peers-as a rule has no role at sentencing, except at capital trials. Trial judges dominate the sentencing process. ${ }^{55}$ Furthermore, the prevalence of guilty pleas means that, before sentencing, most defendants never see a jury. They thus bypass the traditional arbiter of community values, which in times past encouraged repentance and apology. ${ }^{56}$ In those few cases that go to trial or give jurors a role at sentencing, defendants can address the jury as "the conscience of the community." 57 But even here, jurors' role is far from interactive - they cannot, for example, question the defendant, and the defendant rarely addresses them directly. ${ }^{58}$ Offenders determined to express remorse and to apologize may have to resort to the news media to circumvent criminal procedure's barrier of silence.

Context and procedure, in short, discourage the expressions about which the criminal law cares. This tension leaves criminal law in the uneasy position of judging offenders based on expressions it has done little to elicit or probe. It also denies victims, offenders, and their communities any real opportunity to reap the substantial social, psychological, and moral benefits that these expressions carry with them. Frustration, pain, guilt, and alienation replace the potential for closure, relief, healing, and

were intended for the [victims'] relatives" and how he then, "[f]acing a packed courtroom,... went on to speak for minutes about his remorse"). In a few courtrooms, however, the victim might sit in visitors' seats that face both the judge and the offender.

54. See TOBOLOWSKY, supra note 42 , at $96-98$.

55. See, e.g., Morris B. Hoffman, The Case for Jury Sentencing, 52 DuKE L.J. 951, 953 (2003); Jenia Iontcheva, Jury Sentencing as Democratic Practice, 89 VA. L. REv. 311, 314 (2003); Adriaan Lanni, Note, Jury Sentencing in Noncapital Cases: An Idea Whose Time Has Come (Again)?, 108 YALE L.J. 1775, 1790 (1999). Even though the Supreme Court has begun to endorse a role for jurors at sentencing, they are unlikely to dominate the process any time soon. See infra note 296.

56. See, e.g., Witherspoon v. Illinois, 391 U.S. 510,519 \& n. 15 (1968) (explaining that juries inject "contemporary community values" into punishment decisions); LAWRENCE M. FRIEDMAN, CRIME AND PUNISHMENT IN AMERICAN HISTORY 25 (1993) (explaining that colonial Americans prized the jury trial as "an occasion for repentance and reintegration").

57. Witherspoon, 39l U.S. at 519.

58. See GeORge P. FletCher, With Justice for SOME: Protecting Victims' Rights in CRIMINal Trials 228, 236 (1996); see also John H. Langbein, Historical Foundations of the Law of Evidence: A View from the Ryder Sources, 96 COLUM. L. REV. 1168, 1170-71 (1996) (noting the jury's "epochal transformation from active neighborheod investigators to passive triers"). 
reconciliation. This, in turn, undercuts some of the core substantive goals of the criminal law.

\section{Remorse and Apology in the Literature}

Scholars have given scant attention to the roles of remorse and apology in the criminal justice system. ${ }^{59}$ Tracking the emphasis of the law, many commentators have focused on the pragmatic, administrative, and epistemological difficulties of using them as proxies for individual badness. ${ }^{60}$ For example, Michael O'Hear criticizes remorse-based sentence discounts as unworkable and unfair ways of using remorse and apology to determine how much punishment offenders deserve. ${ }^{61}$ Likewise, Martha Grace Duncan and Margareth Etienne both note that remorse-based sentencing in practice often correlates poorly with the offender's actual remorse or blameworthiness. ${ }^{62}$ Some scholars-including Jean Hampton, Jeffrie Murphy, Austin Sarat, and Robert Wuthnow-eschew pragmatic and administrative concerns. Instead, they look more deeply and theoretically at how remorse relates to punishment, particularly how remorse and apology fit within prevailing theories of punishment. ${ }^{63}$ Stephen Garvey goes further

59. See supra note 7.

60. See infra notes 74-77 and accompanying text; see also Eisenberg et al., supra note 21 (exploring why expressions of remorse influence jurors' sentencing decisions and identifying several methodological challenges for the future systematic analysis of the relationship between remorse and sentencing outcome); Sundby, supra note 16, at 1597, 1588-98 (contending that, because capital jurors give great weight to remorse, capital defense counsel "would be greatly remiss to pursue a run-of-the-mill strategy of challenging the prosecution's case for failing to prove guilt beyond a reasonable doubt before weighing carefully the potential impact such a strategy will have on the penalty phase").

61. See O'Hear, supra note 7, at 1542-60 (listing dangers including excessive litigation, disparity, discrimination, failing to encourage rehabilitation, dishonesty in sentencing, difficulty in discerning remorse, and chilling the exercise of Fifth Amendment rights). O'Hear argues that appellate courts should abandon the fiction that U.S. Sentencing Guideline section 3E1.1 is pegged to remorse. Instead, he advocates the approach that trial courts more or less already take, which ties sentencing discounts to guilty pleas because these are efficient and spare the system trials. See id. at 1560-61. Our argument is exactly the opposite-courts and commentators are too focused on narrow notions of efficiency and not focused enough on the power and benefits of remorse.

62. See Duncan, supra note 22 , at $1472-73$ (noting that judges and jurors often mistakenly view juvenile offenders as remorseless, and contending that these offenders' denials and lack of remorse are often understandable); Margareth Etienne, Remorse, Responsibility, and Regulating Advocacy: Making Defendants Pay for the Sins of Their Lawyers, 78 N.Y.U. L. REV. 2103 (2003) [hereinafter Etienne, Remorse] (arguing that federal judges penalize defendants under section $3 \mathrm{E} 1.1$ of the Federal Sentencing Guidelines by equating zealous advocacy with remorselessness); Margareth Etienne, The Declining Utility of the Right to Counsel in Federal Criminal Courts: An Empirical Study on the Diminished Role of Defense Attorney Advocacy Under the Sentencing Guidelines, 92 CAL. L. REV. 425 (2004) (same, using a qualitative empirical study to confirm this claim).

63. See, e.g., Jean Hampton, Correcting Harms Versus Righting Wrongs: The Goal of Retribution, 39 UCLA L. REV. 1659, 1677-78 (1992); Jeffrie G. Murphy, Repentance, 
and tries to build a new theoretical framework for punishment around those concepts. $^{64}$ Not all of these scholars embrace the individual badness model. ${ }^{65}$ But even those who do not, such as Garvey, rarely connect their views to actual on-the-ground institutions, practices, and procedures. The one partial departure is R.A. Duff, who discusses in general terms how criminal mediation could promote apology, reparations, reconciliation, moral education, and reform. ${ }^{66}$

Commentators who go further fall into two main camps. The first is the "apology as sanction" camp. Scholars in this camp either argue for (Amitai Etzioni, Dan Kahan, Eric Posner, and David Skeel) ${ }^{67}$ or against (Sharon

Punishment, and Mercy, in REPENTANCE, supra note 36, at 143, 148-51 (discussing relationship of repentance to deterrence and retributivism); Sarat, supra note 16, at 168-72 (discussing general relationship of remorse to punishment); Wuthnow, supra note 36, at 174-79 (discussing historical role of repentance in society's treatment of criminals and its relationship to modern theories of punishment); see also HERBERT MORRIS, Guilt and Suffering, in ON GUILT AND INNOCENCE 89, 104-08 (1976) (arguing that punishment by itself never can be restorative of personal relationships, but that accompanying feelings of guilt, contrition, and repentance can provide the grounds for genuine restoration); B. Douglas Robbins, Comment, Resurrection from a Death Sentence: Why Capital Sentences Should Be Commuted upon the Occasion of an Authentic Ethical Transformation, 149 U. PA. L. REV. 1115, 1140-44 (2001) (reviewing relationship of remorse to various theories of punishment).

64. See Garvey, Punishment as Atonement, supra note 9, at 1802 (using concepts of repentance, apology, reparation, and penance to articulate a theoretical model of punishment "aimed at the expiation of the wrongdoer's guilt and his reconciliation with the victim and the community").

65. Murphy, for instance, recognizes that "[r]epentance may be conceptualized as either an interior mental act or as an act with an essential social dimension." JEFFRIE G. MURPHY, GETTING EVEN 41 (2003).

66. R.A. Duff, Punishment, COMmunication, And COMmunity 93-99 (2001). Duff goes on to talk in general terms about how types of punishment, proportionality, sentencers, and similar procedures affect the messages sent by punishments. Other exceptions include a few pages in the following: Bibas, supra note 10, at 1368-70; Carrie J. Petrucci, Apology in the Criminal Justice Setting: Evidence for Including Apology as an Additional Component in the Legal System, 20 BEHAV. SCI. \& L. 337, 346-47 (2002); Simons, supra note 24, at 34; and Wuthnow, supra note 36 , at $179-84$.

Foreign scholars have gone further in addressing how criminal mediation might work to bring about apology, healing, reconciliation, and reform. This is a significant theme in the German literature, for example, where mediation often is called the "third way" after punishment and civil commitment. See Detlev Frehsee, Restitution and Offender-Victim Arrangement in German Criminal Law: Development and Theoretical Implications, 3 BUFF. CRIM. L. REV. 235 (1999) (reviewing history and current state of victim-offender mediation in Germany); see also William T. Pizzi \& Walter Perron, Crime Victims in German Courtrooms: A Comparative Perspective on American Problems, 32 STAN. J. INT'L L. 37 (1996) (comparing American and German victims' relative rights to participate in criminal proceedings).

67. See Kahan, supra note 9, at $634,637-52$ (describing the use of apology as a "contrition penalty" and arguing that such penalties, along with other shaming sanctions, are effective and appropriate in certain circumstances); Kahan \& Posner, supra note 45, at 365 (making a similar argument in the context of white-collar crime); David A. Skeel, Jr., Shaming in Corporate Law, 149 U. PA. L. REV. 1811 (2001) (advocating use of apology as a shaming penalty for corporate crime); Amitai Etzioni, Back to the Pillory?, AM. SCHOLAR, Summer 1999, at 43, 44. Additional proponents of expanding the use of apology as a sanctioning mechanism include Katharine Baker and Jayne Barnard. See Katharine K. Baker, Sex, Rape, and Shame, 79 B.U. L. REV. 663, 699-701 
Lamb and Toni Massaro ${ }^{68}$ using apology to punish. Debate within this camp is a subset of the larger debate over the wisdom of shaming sanctions. The concern is not with how criminal procedure can promote healing, repentance, and reconciliation, but rather with whether court-ordered apology can deter crime.

The second camp is the "restorative justice" camp. As its undisputed leader, John Braithwaite, ${ }^{69}$ defines the term, restorative justice "is a process whereby all the parties with a stake in a particular offense come together to resolve collectively how to deal with the aftermath of the offense and its implications for the future." ${ }^{.70}$ Restorativists consider apology and remorse important as part of a holistic process. They hope that offenders will recognize the wrongfulness of their conduct, make amends with their victims and the community, and try to restore the moral balance by making actual or symbolic reparations. ${ }^{71}$ Restorative justice, however, does not seek to reform criminal procedure to broaden and deepen the values served by criminal punishment. Instead, the restorative processes of remorse, apology, and reparation are supposed to be complete alternatives to punishment. ${ }^{72}$

(1999); Jayne W. Barnard, Reintegrative Shaming in Corporate Sentencing, 72 S. CAL. L. REV. 959, 1001 (1999).

68. See Sharon Lamb, The Psychology of Condemnation: Underlying Emotions and Their Symbolic Expression in Condemning and Shaming, 68 BROOK. L. REV. 929, 953, 951-56 (2003) (discussing the relationship of apology and remorse to shaming punishments and arguing that "criminals and other wrongdoers will derive little benefit from wholesale rejection and the ending of a relationship through shaming acts"); Toni M. Massaro, Shame, Culture, and American Criminal Law, 89 MiCH. L. REV. 1880 (1991) (reviewing the use of apologies as shaming sanctions and arguing generally that dominant social and cultural traditions in the United States render shaming sanctions ill advised). Norval Morris and Michael Tonry also take this view. See NORVAL MORRIS \& MiCHAEL TONRY, BETWEen PRISON AND PROBATION: INTERMEdIATE PUNISHMENTS IN A RATIONAL SENTENCING SYSTEM 5 (1990).

69. Braithwaite is "the world's preeminent scholar of restorative justice." Erik Luna, Introduction: The Utah Restorative Justice Conference, 2003 UTAH L. REV. 1, 10.

70. John Braithwaite, Restorative Justice: Assessing Optimistic and Pessimistic Accounts, in 25 CRIME AND JUSTICE: A REVIEW OF RESEARCH 1, 5 (Michael Tonry ed., 1999) (internal quotation marks omitted) (quoting definition of restorative justice formulated by Tony Marshall); see also Luna, supra note 69, at 3 (adopting Braithwaite's definition).

71. See Erik Luna, Punishment Theory, Holism, and the Procedural Conception of Restorative Justice, 2003 UTAH L. REV. 205, 293-94 (explaining the role of remorse and apology in restorative processes).

72. See, e.g., Stephen P. Garvey, Restorative Justice, Punishment, and Atonement, 2003 UTAH L. REV. 303, 303 (noting that proponents of restorative justice "insist on the total elimination of punishment" and critiquing this position); Paul H. Robinson, The Virtues of Restorative Processes, the Vices of "Restorative Justice," 2003 UTAH L. REV. 375, 377 ("[T]he literature by the leaders of the restorative justice movement make[s] clear that they conceive of restorative processes not simply as a potentially useful piece of, or complement to, the criminal justice system, but as a substitute for it." (citing John Braithwaite, A Future Where Punishment Is Marginalized: Realistic or Utopian?, 46 UCLA L. REV. 1727, 1746 (1999))). But cf. John Braithwaite, Holism, Justice, and Atonement, 2003 UTAH L. REV. 389, 404 [hereinafter Braithwaite, Holism] (suggesting that punishment might be necessary as a fallback "when criminals eschew atonement, ... to affirm [the] moral order and to vindicate victims"); Howard Zehr, Book Review, 43 BRIT. J. CRIMINOLOGY 653, 654 (2003) (reviewing THE SPIRITUAL 


\section{THE BROADER VALUe OF REMORSE AND APOLOGY}

What accounts for this troubling dissonance between criminal law and procedure? Earlier, we explained that criminal procedure ignores remorse and apology because it emphasizes procedural values such as autonomy, efficiency, and fairness to the exclusion of substantive concerns. In this Part we argue that the criminal law's misguided focus on the individual badness model only exacerbates this problem. The individual badness model treats remorse and apology as yardsticks for an offender's need for deterrence and retribution. That model, however, suffers from serious pragmatic, administrative, and conceptual problems on both an internal and an external level. Internally, an offender's need for retribution and deterrence often correlates poorly with remorse and apology. Externally, the individual badness model overlooks remorse and apology's relational dimension. Remorse and apology are not simply tools for diagnosing the appropriate punishments for individual defendants. They can heal, teach, and reconcile offenders, victims, and communities.

This last point relates to a second, broader trend in the criminal law that has affected its view of remorse and apology. The criminal law views crime and punishment as overwhelmingly about the individual offender and applies deterrence and retribution accordingly. In contrast, a rich and growing body of sociological and psychological work views remorse and apology as social mechanisms that restore relationships and affirm group membership. Other areas of the law, such as civil mediation and reparations, are less constrained by deterrence, retribution, and individualism and have begun to mine these insights. Criminal law can learn from these areas how to integrate the values served by remorse and apology into the day-to-day criminal justice system. Doing so, moreover, does not require abandoning deterrence, retribution, or bedrock procedural values.

\section{A. The Status Quo Revisited}

Assume for the moment that the individual badness model properly seeks to discern each offender's badness and need for punishment. As metrics for punishment, expressions of remorse and apology do not work

RoOTS OF RESTORATIVE JUSTICE (Michael L. Hadley ed., 2001)) ("[R]estorative justice advocates have done a disservice by positioning restoration and retribution as mutually exclusive adversaries. As a restorative justice advocate who initially popularized this dichotomy, I have personally taken this argument to heart and changed my approach accordingly." (citation omitted)). This last review is an isolated, brief, and recent change of heart, not apparently shared by Braithwaite, the leading figure in the field. For the most part, restorative justice academics see themselves as at odds with criminal punishment. See infra Section II.C. 
very well. Indeed, much of the commentary on remorse and apology in criminal justice focuses on this fact. We already have outlined some of these concerns, such as cognitive dissonance and contextual obstacles to apologizing and expressing remorse in the courtroom. ${ }^{73}$ One can also doubt judges' and jurors' ability to gauge the sincerity and depth of expressions of remorse and apology. ${ }^{74}$ Thus, the justice system may reward well-executed fakery and the "acquired skill" of expressing "appropriate" attitudes in the courtroom. ${ }^{75}$ In addition, overemphasis on remorse and apology may punish defendants not for their inherent badness but instead for their attorneys' zealous advocacy or for their own exercise of their Fifth and Sixth Amendment rights. $^{76}$ And sentencers' perceptions of remorse may "implicate much deep-seated racial, cultural, class, and gender baggage.",

Our criticism of how the criminal law accounts for remorse and apology goes deeper, so we will not dwell on these problems here. We flag them simply to illustrate how thoroughly the individual badness model has colored the criminal law's evaluation of remorse and apology. If the internal critiques of the individual badness model are correct, then the law's stance disserves important substantive values such as fairness and equal treatment, and criminal procedure does nothing to correct it.

A more interesting, and for our purposes more significant, question is whether traditional deterrence theorists or retributivists should be so concerned with adjusting an offender's sentence based on his expression of remorse or apology. Take deterrence first. A basic conception of deterrence asserts that punishment is justified because it averts future harm by imposing costs on undesirable conduct. The classic approach to deterrence

73. See supra notes $37-48$ and accompanying text.

74. See United States v. Hendrix, 505 F.2d 1233, 1236 (2d Cir. 1974) ("The effort to appraise 'character' is, to be sure, a parlous one, and not necessarily an enterprise for which judges are notably equipped by prior training."); United States v. Torres, No. 84 CR 583, 1987 WL 15173, at *2 (N.D. Ill. July 24,1987 ) ("[T]here is no way to know whether a defendant is truly remorseful for having committed the offense or whether his remorse is rather for his having been caught ...."), aff'd, 809 F.2d 429 (7th Cir. 1987); Amitai Etzioni, Introduction, in REPENTANCE, supra note 36, at 1, 9; O'Hear, supra note 7, at 1549-51.

75. O'Hear, supra note 7, at 1555 . These difficulties, however, are not insurmountable. See infra Section III.G.

76. See, e.g., Etienne, Remorse, supra note 62, at 2111 (arguing that federal judges penalize defendants under section $3 \mathrm{E} 1.1$ of the Federal Sentencing Guidelines by equating zealous advocacy with remorselessness); O'Hear, supra note 7, at 1556-60 (arguing that the incorporation of remorse into section 3E1.1 threatens to chill the exercise of defendants' First, Fifth, and Sixth Amendment rights).

77. O'Hear, supra note 7, at 1555; see also United States v. Vance, 62 F.3d 1152, 1158 (9th Cir. 1995) (observing that "penetrating judicial examination of the criminal's soul" in practice can amount to "lenience toward those who cry more easily, or who have sufficient criminal experience to display sentiment at sentencing"). 
treats it strictly as a cost-benefit analysis. ${ }^{78}$ To the extent that the expected penalty for committing a crime outweighs the expected benefit, a potential wrongdoer will be deterred..$^{79}$ Remorseful and apologetic wrongdoers, the basic thinking goes, need less deterrence than do unremorseful ones for at least two reasons. First, remorseful and apologetic wrongdoers, by virtue of the pangs of conscience associated with such expressions, "pay a higher price" than do unremorseful offenders for their wrongful conduct. ${ }^{80}$ Hence, it makes sense to lower their sanction accordingly. Second, remorseful and apologetic wrongdoers, simply by virtue of being remorseful and apologetic people, are "less likely to offend again" in the future. "As a result, the community needs to be less worried about the offender and can afford to be more lenient." $" 82$

This reasoning is dubious at best. As of yet, psychology, psychiatry, sociology, and criminology have not empirically linked expressions of remorse and apology to a decreased need for specific deterrence of particular offenders. ${ }^{83}$ Moreover, crediting the remorseful offender with costs incurred may well undercut general deterrence of other potential offenders, encouraging them to discount their expected penalty by the remorse-apology discount. They may assume that, if they do get caught, they can lower their penalty by acting remorseful and apologizing. The deterrent message of the expected sanction shifts from "If you do $X$, you will suffer $Y$ " to "Don't worry about suffering $Y$ if you do $X$, as long as you can seem to feel bad about it." ${ }^{\prime 4}$ Finally, the narrow sentencing discount from appearing sorry at sentencing obscures the more robust benefits to offenders and victims of remorse outside of sentencing. Offenders learn to embrace remorse and apology not as steps to healing and reintegration, but as ways to lighten their sentences if they are caught. ${ }^{85}$

78. As we discuss in Section III.F, however, modern theorists reconceptualize deterrence as influencing the social norms and meanings of crimes, which leaves more room for remorse and apology.

79. See, e.g., JeRemy Bentham, An InTROduction to the PRINCIPLes of Morals AND LEGISLATION 170 \& n.1 (Clarendon Press 1907) (1789); Gary S. Becker, Crime and Punishment: An Economic Approach, 76 J. POL. ECON. 169, 180 (1968); Dan M. Kahan, The Secret Ambition of Deterrence, 113 HARV. L. REV. 413, 425 (1999) (reviewing basics of deterrence theory).

80. See, e.g., Simons, supra note 24 , at 31 .

81. Sarat, supra note 16, at 170; see also, e.g., In re Rubinstein, 506 N.Y.S.2d 441, 442 (App. Div. 1986); Murphy, supra note 63, at 148-49; supra notes 25-29 and accompanying text.

82. Sarat, supra note 16 , at 170 .

83. See Petrucci, supra note 66, at 360, 359-60 (noting the need for additional empirical studies "to determine whether it is apology itself or some other closely related variable that is associated or causally linked with reduced recidivism").

84. See Dan M. Kahan \& Martha C. Nussbaum, Two Conceptions of Emotion in Criminal Law, 96 COLUM. L. REV. 269, 360 (1996) (explaining how the criminal law's response to emotions can alter the deterrent message sent to offenders).

85. See, e.g., Wuthnow, supra note 36 , at 179 ("[P]roponents of deterrence point out that repentance should not be considered in sentencing because the purpose of criminal prosecution is 
Retributivism runs into similar problems. Classical (or grievance) retributivism holds that an offender should be punished "because, and only because, [he] deserves it." punishment is commensurate with the objective moral seriousness of the offense. In this sense, classical retributivism is backward-looking because it is properly concerned only with the offender's wrongful act and the circumstances surrounding it. ${ }^{87}$ But if the conduct and circumstances that matter to garden-variety retributivism are so limited, retributivists should not care about post-offense remorse, apology, or repentance. In most cases, these expressions neither lessen the culpability of the act itself nor mitigate any physical or pecuniary harm suffered by the victim. ${ }^{88}$ As Murphy puts it, "In general, the wrongfulness of conduct at one time will not be affected by repentance at a later time." 89

One could still justify lowering a remorseful offender's sentence under another version of retributivism known as character retributivism. According to character retributivism, a wrongdoer's deserts are a function not merely of his wrongful acts, but also of his character. ${ }^{90}$ But here too, real questions exist. On the one hand, the remorseful and apologetic wrongdoer seems to reveal a better character than does the hardened one. On the other hand, he also reveals a moral nature that he must have suppressed to commit the crime in question. Contrast him with the remorseless wrongdoer, who is simply a "crude and unreflective thug"91

not so much to mete out punishment on the basis of the offender's own character but as an example to other potential offenders."). But see infra Section III.F (acknowledging merit in a more modern version of deterrence that focuses on the criminal law's power to influence values and the formation of preferences).

86. Michael S. Moore, The Moral Worth of Retribution, in RESPONSIBILITY, CHARACTER, AND THE EMOTIONS: NEW ESSAYS IN MORAL PSYCHOLOGY 179, 179 (Ferdinand Schoeman ed., 1987); see also IMMANUEl KANT, THE METAPHYSICS OF MORALS 140-45 (Mary Gregor ed. \& trans., Cambridge Univ. Press 1991) (1797); IMMANUEL KANT, THE PHILOSOPHY OF LAW 198 (W. Hastie trans., Edinburgh, T. \& T. Clark 1887) (1796-1797); MichaEl MoORE, PlaCing BLAME: A GENERAL THEORY OF THE CRIMINAL LAW 153 (2002).

87. See, e.g., Darryl K. Brown, Third-Party Interests in Criminal Law, 80 TEX. L. REV. 1383, 1408 (2002) ("Retributivism limits attention to an offender's mental state, conduct, and the harm he caused . . ."); Dan Markel, Against Mercy, 88 MINN. L. REV. 1421, 1445 (2004) (noting that "[r]etribution is often characterized as being concerned with the offender's past wrongdoing" and that retributivism generally holds that punishment "should be commensurate to the seriousness of the wrong and [the offender's] blameworthiness in committing it").

88. See Murphy, supra note 63, at 149 ("I typically do not cease to have a grievance against you simply because you are now sorry that you wronged me; nor do your debts to me disappear merely because you now lament those acts that put you into debt to me.").

89. Id. Perhaps mercy justifies lighter sentences for repentant offenders, but mercy is in tension with retribution because it sidesteps desert and allows unequal treatment. See Markel, supra note 87, at 1425; Murphy, supra note 63, at 149.

90. See Murphy, supra note 63, at 149; see also Robbins, supra note 63, at 1118 (arguing that character retributivism requires the commutation of the death sentences of genuinely remorseful and hence-according to Robbins - ethically transformed offenders).

91. Murphy, supra note 63 , at 150 . 
who never really thinks things through. Better yet, contrast him with a wrongdoer who suffers from psychosis or other mental illness for which lack of remorse is a known symptom. ${ }^{92}$ These remorseless wrongdoers may not be as bad as the offender with a fully formed moral personality who appreciates the wrongfulness of his crime and commits it anyway. Indeed, the insanity and diminished-capacity defenses exist precisely to give effect to this intuition: Wrongdoers who do not fully appreciate the wrongfulness of their crimes - and so are less likely to express remorse or apologize-are sometimes less blameworthy than those who do. ${ }^{93}$

If one focuses on individual badness, in other words, it is hard to understand why remorse and apology should matter as much as they do. This problem, though, is not attributable solely to the individual badness model itself. The model is symptomatic of a deeper strain of thinking in contemporary criminal law scholarship: a focus on the individual offender, to the exclusion of victims, society, and their relations with the offender. ${ }^{94}$ Criminal sentencing and punishment have long been preoccupied with individual offenders. Indeed, "by the 1970s and 1980s, there was a consensus within the academy that all of the most important theoretical questions in the criminal law were about individuals: individual 'selfcontrol,' individual dangerousness, and individual culpability." 95 One consequence is that crime is viewed largely as a matter between the

92. See Am. Psychiatric Ass'n, Diagnostic and Statistical Manual of Mental DISORDERS $\S 301.7$, at 650 (4th ed. 1994) (listing as one of the seven diagnostic criteria for Antisocial Personality Disorder "lack of remorse, as indicated by being indifferent to or rationalizing having hurt, mistreated, or stolen from another").

93. See, e.g., MODEL PENAL CODE § $210.3 \mathrm{cmt}$. (1980) (noting that "diminished responsibility ... achieves a closer relation between criminal liability and moral guilt" because "[m]oral condemnation must be founded, at least in part, on some perception of the capacities and limitations of the individual actor"); Herbert Morris, Sex, Shame, and Assorted Other Topics, 22 QUINNIPIAC L. REV. 123, 131 (2003) (noting that individuals who suffer from a mental illness that diminishes culpability for their wrongful conduct are appropriately viewed as subjects for treatment instead of punishment); Christopher Slobogin, An End to Insanity: Recasting the Role of Mental Disability in Criminal Cases, 86 VA. L. REV. 1199, 1202 (2000) (explaining that the purpose of the insanity defense is to help distinguish between those offenders who are blameworthy and culpable and those who are not). The same intuition underlies the criminal law's general ranking of recklessness as a more blameworthy state of mind than simple negligence. See MODEL PENAL CODE $§ 2.02(2)(\mathrm{c})$-(d) (1985).

94. Compared to private law areas, American criminal law seems more focused on society. But compared with European criminal law, or with what American criminal law could be, our current criminal law is largely about the individual offender, his rights, his guilt, and his need for punishment. Victims and others play minor roles at best.

95. Victoria F. Nourse, Reconceptualizing Criminal Law Defenses, 151 U. PA. L. REV. 1691, 1700 (2003); see also Katyal, supra note 41, at 1311-12 ("Most law professors . . think about crime as a solo enterprise-a tendency reinforced by the individualist prism of microeconomics and the case-driven method of studying specific parties."); Nourse, supra, at 1695 ("Since the 1970 s, there has been an often unstated consensus that the proper level of analysis of the criminal law is at the individualized level of mind or conduct (whether of individual defendants or the collective sum of all potential defendants)."). 
offender and the state; victims and community have little role to play. ${ }^{96}$ Another consequence is that the idea of individual dispositions toward or against criminality drives much of the thinking about how best to control and respond to crime. ${ }^{97}$

These tendencies shape criminal law's stance toward expressions of remorse and apology. If criminal law and punishment are about responding to an individual's willingness to act on his criminal disposition, then remorse and apology do not deserve major roles in criminal procedure. Individual offenders, in the law's view, will be disposed to repent and apologize, or they will not. Either way, the criminal law, guided by the twin aims of deterrence and retribution, will respond accordingly. Criminal procedure will have no reason to focus on encouraging expressions of remorse and apology from offenders to their victims and the community. Instead, it can concern itself with the more pressing task of safeguarding certain core procedural values: efficiency, fairness, and individual rights. This is exactly what we see in the status quo. ${ }^{98}$

\section{B. The Broader Value of Remorse and Apology}

\section{Crime as a Relational Concept}

Crime and punishment are about more than simply controlling offenders as individuals. As any crime victim can tell you, crime also disrupts status relationships among offenders, victims, and communities. If you are mugged or your car is broken into, you are distressed not just because you lose the money in your wallet or must pay to replace your radio. You likely feel violated and belittled by the perpetrator and his act. Likewise, the crime distresses other members of the community not simply because they fear losing money or property. The crime also carries a symbolic message from the wrongdoer that the community's norms do not apply to him and that he is superior to the victim and others like him.

This account recognizes that crime and punishment are as much about social norms, social influence, and relations between persons as about

96. See Dubber, supra note 40 , at 851 (noting that the "person of the victim" has "disappear[ed] entirely and emphatically" from criminal law, which aims instead to protect society from "anti-social conduct one expects from anti-social individuals" (internal quotation marks omitted)); Nourse, supra note 95 , at $1700 \&$ n.37.

97. See Brown, supra note 87, at 1406; David Gariand, Ideas, Institutions and Situational Crime Prevention, in ETHICAL AND SOCIAL PERSPECTIVES ON SITUATIONAL CRIME PREVENTION 1, 1-14 (Andrew von Hirsch et al. eds., 2000); see also Dubber, supra note 40, at 849 (explaining that the modern war on crime treats offenders and victims not as persons, but as threatening automata and inefficient nuisances, respectively).

98. See supra Part I. 
individual blame and state-imposed suffering. Dan Kahan has espoused a similar, expressive view of crime. As he puts it, "The distinctive meaning of criminal wrongdoing is its denial of some important value, such as the victim's moral worth." 99 In Kahan's view, theft differs from competition in part because "against the background of social norms theft expresses disrespect for the injured party's worth, whereas competition (at least ordinarily) does not." 100 Along the same lines, Jean Hampton's expressive theory of retribution focuses on the messages that wrongful behavior and sanctions send to victims, offenders, and the community. ${ }^{101}$ Wrongdoing, Hampton explains, sends a "false message" that the victim is worth less than the offender. ${ }^{102}$ The crime announces that the victim does not deserve respect and that the offender can instead use him as a means to an end. ${ }^{103}$

Social psychologists, especially equity theorists, emphasize this relational aspect of wrongdoing. Equity theorists, in discussing both criminal and civil wrongdoing, emphasize that "a wrongdoer's transgression against an injured party results in an inequity in their relationship; that is, the wrong creates a moral imbalance between the parties." 104 This moral imbalance extends beyond the specific victims to the moral and social community whose norms the wrongdoer has flouted. Through his transgression, the wrongdoer sets himself off from that community and sends a symbolic message to it and the victim: $\mathrm{He}$ is not part of the group and does not have to play by its rules. ${ }^{105}$ According to equity theory, punishment seeks to "set the balance right" by mending the breach caused by the wrongdoer and reaffirming social and community norms. ${ }^{106}$ An emerging body of empirical evidence supports this theoretical

99. Kahan. supra note 9, at 597.

100. Id. at 597-98; see id. at 598 ("In effect, the thief's behavior says to the victim, 'you matter so little. relative to me, that I can take your property without your consent."').

101. See Hampton, supra note 63, at 1677.

102. Jean Hampton, An Expressive Theory of Retribution, in RETRIBUTIVISM AND ITS CRITICS 1, 8. 12 (Wesley Cragg ed., 1992).

103. See id. at 8; see also Jean Hampton, Forgiveness, Resentment and Hatred, in JEFFRIE G. MURPHY \& IEAN HAMPTON, FORGIVENESS AND MERCY 35, 44 (1988) ("When someone wrongs another, she cioes not regard her victim as the sort of person who is valuable enough to require better treatment."). Jeffrie Murphy shares this view. See Jeffrie Murphy, Forgiveness and Resentment, in MURPHY \& HAMPTON, supra, at 14, 25.

104. Jennifer K. Robbennolt et al., Symbolism and Incommensurability in Civil Sanctioning: Decision Makers as Goal Managers, 68 BROOK. L. REV. 1121, 1141 (2003); see also Elaine Walster et al., New Directions in Equity Research, 25 J. PERSONALITY \& SOC. PSYCHOL. 151, 153 (1973).

105. See, e.g., Alan Page Fiske \& Philip E. Tetlock, Taboo Trade-Offs: Reactions to Transactions That Transgress the Spheres of Justice, 18 POL. PSYCHOL. 255, 286 (1997) (explaining the ways in which transgressions "throw[] into doubt the taken-for-granted assumptions that are constitutive of [social] order"); Hampton, supra note 63, at 1677-82.

106. See, e.g., Fiske \& Tetlock, supra note 105, at 286 (explaining that punishment is necessary "to restore the moral status quo ante and to reduce whatever cognitive and emotional unease was produced in individual[s] . . by the ... transgression"); Robbennolt et al., supra note 
account. The evidence suggests that jurors, litigants, victims, and even offenders in both criminal and civil cases consider this relational aspect of wrongdoing extremely important. ${ }^{107}$

Mainstream criminal law scholarship has been slow to incorporate these insights regarding the relational dimension of criminal wrongdoing into practical recommendations for criminal justice reforms. But there are a few exceptions. Kahan's expressive theory, for example, drives his pro-shaming stance. ${ }^{108} \mathrm{He}$ has used the same theory to argue for retaining corporate criminal liability and for alternatives to the traditional crackdowns on gangs. ${ }^{109}$ Darryl Brown and Neal Katyal have argued that criminal law's traditional focus on individuals has obscured the key roles of social influence and group identity. ${ }^{110}$ This insight supports new rules and strategies to facilitate extracting information from conspirators. ${ }^{11}$ It also supports extending cooperative, nonpunitive crime-control policies from corporate crime to street crime. ${ }^{112}$ Kyron Huigens endorses Brown's social approach to crime. He grounds this social approach, however, not in consequentialism but in a virtue-based analysis of how interdependent humans must get along in society. ${ }^{113}$ In a similar vein, Stephen Garvey has developed a theory of "punishment as atonement" that seeks to reconcile

104, at 1143, 1139-44 (discussing how criminal and civil punishment restores moral balance by reaffirming the value of victims and social norms and "mending the breach caused by the defendant's reprehensible actions"); see also HERBERT MORRIS, Persons and Punishment, in ON GUILT AND INNOCENCE, supra note 63, at 31, 34 (arguing that crime involves seizing an unfair advantage over law-abiding citizens, so punishment is needed to "restore[] the equilibrium of benefits and burdens by taking from the [wrongdoer] what he owes").

107. See Michelle Chernikoff Anderson \& Robert J. MacCoun, Goal Conflict in Juror Assessments of Compensatory and Punitive Damages, 23 LAW \& HUM. BEHAV. 313, 326-27 (1999); Jonathan Baron \& Ilana Ritov, Intuitions About Penalties and Compensation in the Context of Tort Law, 7 J. RISK \& UNCERTAINTY 17, 25 (1993); Gordon Bazemore \& Mark S. Umbreit, Rethinking the Sanctioning Function in Juvenile Court: Retributive or Restorative Responses to Youth Crime, 41 CRIME \& DELINQ. 296 (1995); E. Allan Lind et al., In the Eye of the Beholder: Tort Litigants' Evaluations of Their Experiences in the Civil Justice System, 24 LAW \& SOC'Y REV. 953 (1990); infra Subsections II.B.2-3, Sections III.A-B (discussing reactions of victims and offenders to apologetic discourse in restorative justice programs).

108. See Kahan, supra note 9.

109. See Dan M. Kahan, Social Meaning and the Economic Analysis of Crime, 27 J. LEGAL STUD. 609, 619, 618-22 (1998) (arguing that corporate crime denigrates societal values and the worth of victims just as much as street crime, and that corporate criminal liability "repudiate[s] the[se] false valuations" and "sends the message' that people matter"); id. at 612-15 (arguing that gang-control strategies that seek to undermine the positive meaning of gang membership are superior to traditional crackdown strategies, which simply reinforce the perceptions that motivate gang membership in the first place).

110. See Brown, supra note 30; Brown, supra note 87; Katyal, supra note 41.

111. See Katyal, supra note 41, at 1381-90.

112. See Brown, supra note 30 , at 1345-57.

113. See Kyron Huigens, Street Crime, Corporate Crime, and Theories of Punishment: A Response to Brown, 37 WAKE FOREST L. REV. 1, 8 (2002); Kyron Huigens, Virtue and Inculpation, 108 HARV. L. REV. 1423, 1460-62 (1995). 
offenders with their victims and reintegrate them into the community. ${ }^{114}$ Unfortunately, Garvey "say[s] little about specific institutions" and does not "develop any concrete proposals for institutional or doctrinal reform." 115

While these scholars' perspectives on criminal law vary significantly, each of their projects recognizes that relational perspectives merit scholarly concern. ${ }^{116}$ An approach to criminal law that focuses exclusively on individual dispositions toward and consequences of criminal behavior is necessarily incomplete. As David Garland explains, we also must heed the "cultural role" of legal rules and practices, or their ability to "create social meaning and thus shape social worlds." 117 This cultural, relational approach does not require abandoning deterrence, retribution, efficiency, or the adversarial process. But the overlooked relational approach could supplement these goals and generate better approaches to crime control. The next Subsection explains how the relational perspective changes our understanding of how remorse and apology can and should matter to the criminal law.

\section{Remorse and Apology as Relational Concepts}

Crime is about more than "microeconomic concerns with individual behavior." "18 So too, expressions of remorse and apology are about more than predicting future dangerousness or determining just deserts. To be sure, these expressions could offer some insight into an individual offender's moral orientation - the focus of the individual badness model. ${ }^{119}$

114. See Garvey, Punishment as Atonement, supra note 9, at 1801,1804 ; see also Simons, supra note 24, at 33-54 (applying Garvey's model of punishment as atonement to reconceptualize the use of cooperators in criminal law).

115. Garvey, Punishment as Atonement, supra note 9, at 1804.

116. See, e.g., Brown, supra note 30 , at 1352 (discussing importance of crime-control policies that "aim[] to reintegrate offenders into society rather than shame them in an unproductive, alienating fashion"); Garvey, Punishment as Atonement, supra note 9, at 1809-10 (analogizing criminal wrongdoing to sin because both essentially are about damage to important relationships-the sinner's to his relationship with God and the wrongdoer's to his relationship with the community and its members); Katyal, supra note 41, at 1356-58 (arguing that an effective "flipping" strategy for prosecutors requires an emphasis on repentance, salvation, and the ritualized return of a wrongdoer to the community of law-abiding citizens). Victoria Nourse has similarly stressed the importance of appreciating the relational aspects of crime. See Nourse, supra note 95, at 1692, 1701 (arguing that "[o]ne must look to 'how people will respond' to the law and what relations they will create in response" to understand fully the effect of a law and that an appreciation of "sociai norms, status relations, and culture more generally" is necessary for a complete understanding of the criminal law).

117. David Garland, Punishment and Culture: The Symbolic Dimension of Criminal Justice, in 11 STUdies IN LAW, POLITICS, AND SOCIETY 191, 191 (Austin Sarat \& Susan S. Sibley eds., 1991) (emphasis omitted).

118. Katyal, supra note 41, at 1398.

119. Cf. supra Section II.A (noting the practical and theoretical difficulties of using remorse and apology to gauge an offender's individual badness and need for deterrence and retribution). 
But they also function as essentially social mechanisms of healing, reconciliation, moral education, and reintegration.

Apology, expressions of remorse, and other mea culpas are secular remedial rituals. They both teach and reconcile by reaffirming societal norms and vindicating victims. ${ }^{120}$ As such, they are concerned not just with individual dispositions but also with membership in a particular moral community. In Nicholas Tavuchis's words, an apology "is [a] quintessentially social, that is, a relational symbolic gesture occurring in a complex interpersonal field."121 To apologize and repent for one's wrongdoing is to expiate, to make amends. It is also to commit visibly and morally to the norms that govern group affiliation and determine group membership. ${ }^{122}$ Genuine apologies and expressions of remorse, in other words, dissociate oneself from one's wrongful past and make a plea for reconciliation. ${ }^{123}$ They are, as Tavuchis emphasizes, fundamentally relational. Remorse and apology are thus important to the crime-control projects of scholars like Brown, Kahan, and Katyal, though the traditional individual badness model ignores this role. ${ }^{124}$ Blinded by that model, criminal law scholars and commentators too often overlook this interpersonal dimension of remorse and apology. ${ }^{125}$

120. See TAVuCHIS, supra note 12 , at 13 ("Genuine apologies... may be taken as the symbolic foci of secular remedial rituals that serve to recall and reaffirm allegiance to codes of behavior and belief whose integrity has been challenged by transgression, whether knowingly or unwittingly."); see also, e.g., Donna L. Pavlick, Apology and Mediation: The Horse and Carriage of the Twenty-First Ceniury, 18 OHIO ST. J. ON DISP. RESOL. 829, 845, 843-46 (2003) ("Apology dispels the perception that the victim is being ignored [and] validates the victim." (citation omitted)); Hiroshi Wagatsuma \& Arthur Rosett, The Implications of Apology: Law and Culture in Japan and the United States, 20 LAW \& SOC'Y REV. 461, 461 (1986) (characterizing apology as "a crucial element in the recognition and restoration of human relationship"); infra Section II.C.

121. TAVUCHIS, supra note 12 , at 14 ; see also id. at 7 (noting the "essential relational character of apology"); Petrucci, supra note 66, at 343 (noting that an "interpersonal orientation," "stress[ing] a concern for the relationship between the victim and offender," is "a key ingredient" in an effective apology (internal quotation marks omitted)).

122. See, e.g., Luna, supra note 71 , at 294 ("Genuine remorse... signals the offender's affirmation of the legal norms of a community and his desire to be part of legitimate society."); Pavlick, supra note 120, at 846 (discussing how remorse and apology "emphasize[] and reinforce[] the human values implicit to membership or 'recertification' in any moral community" (citation omitted)).

123. See, e.g., Taft, supra note 14, at 1140 (explaining how an apologetic offender, while accepting responsibility for his actions, also commits himself to repent for his wrongful ways); Wagatsuma \& Rosett, supra note 120, at 475 ("An apology suggests change in attitude when the apologizer expresses remorse for past hurt and the commitment that future behavior will not be hostile and will make up for the rupture in relationship created by the hurtful act... [A]n apologizing individual splits herself into two parts, the part that is guilty of an offense and the part that disassociates itself from the delict and affirms a belief in the offended rule.").

124. See, e.g., Katyal, supra note 41, at 1316 (predicating project on "influential [psychological] research [that] focuses on how group membership changes an individual's personal identity to produce a new social identity").

125. See supra notes 59-68 and accompanying text. 
Sociologists, social psychologists, and scholars in other fields of law do not ignore this relational dimension. A rich and growing body of literature explores how remorse and apology build social norms, educate, and repair breaches in communities and relationships caused by wrongdoing. ${ }^{126} \mathrm{~A}$ broad consensus now supports Tavuchis's central point: Because remorse and apology are fundamentally relational, any apologetic discourse must be "dyadic," reflecting "an interaction between the primordial social categories of Offender and Offended." 27 Contrite offenders, in other words, do not just apologize for something. They also apologize to someone-their victims, their community, their family and their friends. ${ }^{128}$ Only by doing so can the remorseful offender "seek[] to re-affirm shared values with the receiver[] and look[] for re-certification of membership in the moral community." ${ }^{29}$ And only in this way can the victim and others hurt by the wrong experience healing. ${ }^{130}$

For this reason, many commentators view a face-to-face interaction between offender and offended as essential to effective expressions of remorse and apology. As Erin O'Hara and Douglas Yarn explain, "Remorse and its accompanying sorrow are often conveyed with body language and facial expression in face-to-face apologies." 131 These interactions allow nuanced communication that contextualizes the offender's crime and the

126. See, e.g., sources cited supra note 120 and infra Subsection II.B.3 (examining the increasing attention to apology in civil mediation). Prior to Tavuchis's work, only Wagatsuma and Rosett, in their comparative study of the role and uses of apology in Japan and United States, see Wagatsuma \& Rosett, supra note 120, had critically examined the importance of expressions of remorse and apology to social norms and the reconciliation of transgressors to their victims and communities. Hence Tavuchis, whose work appeared in 1991, noted that, in his attempt to explore the "wide[] social import" of apology, "[a]n extensive search of diverse sources, including anthropology, psychology, law, diplomacy, etiquette manuals, and literature ... was not, for the most part, fruitful." TAVUCHIS, supra note 12, at 3. Moreover, "sociology . . . and linguistics ... had little to offer in the way of a sustained analysis of the essentials, forms, and functions of apology." Id.

127. TAVUCHIS, supra note 12 , at 46 (emphasis omitted); see also Taft, supra note 14, at 1139 .

128. See TAVUCHIS, supra note 12, at 47 ("[A]pology is a relational concept and practice that necessarily requires an individual or collective Other to realize itself."); Taft, supra note 14, at $1142-43$ (" $\mathrm{A}]$ pology does not exist in isolation; it is, rather, an intensely relational process that cannot be understood alone any more than a promise could be understood without reference to promisor and promisee.").

129. Pavlick, supra note 120 , at 836 (citations omitted); see also DuFF, supra note 66, at 114 (arguing that a wrongdoer owes an apology not only to the direct victim of the crime but also to the community as a whole, "for the wrong done to the individual victim is also a wrong against the community, which shares that wrong and whose values have been flouted").

130. See infra notes 147-152 and accompanying text.

131. Erin Ann O'Hara \& Douglas Yarn, On Apology and Consilience, 77 WASH. L. REV. 1121 , 1134-35 (2002); see id. at 1135 ("More distant apologies often require explicit, and perhaps more extreme, statements of sorrow and regret."); see also Petrucci, supra note 66, at 343 (noting that face-to-face interactions are central to effective apologies); Strang \& Sherman, supra note 42 , at 28 . 
harm done. ${ }^{132}$ An offender "cannot simply rationalize the crime as being minor or harmless when a real person stands in front of him describing the physical and emotional pain directly flowing from his behavior." 133 By humanizing the transgression and its consequences, face-to-face interaction can break down pride, fear, pain, anxiety, and other barriers to accepting responsibility and thus pave the way for genuine repentance. ${ }^{134}$ Offenders can come to see that their crimes had real-world consequences and that their victims want and need to understand why the crime happened. ${ }^{135}$ Victims, likewise, can learn why the crime happened, receive needed assurance that it was not their fault, overcome their resentment, and see offenders as redeemable human beings. ${ }^{136}$ The entire process can provide a starting point for forgiveness and reintegration. ${ }^{137}$

When offenders express genuine remorse in person to those offended, the effects can be profound. ${ }^{138}$ The news media and popular press are full of

132. See Kathy Elton \& Michelle M. Roybal, Restoration, A Component of Justice, 2003 UTAH L. REV. 43, 54 (observing that storytelling and dialogue between a victim and an offender can result in "obtaining a greater understanding of each other's perspective through forthright and emotionally-intense dialogue"); see also Mark W. Bakker, Comment, Repairing the Breach and Reconciling the Discordant: Mediation in the Criminal Justice System, 72 N.C. L. REV. 1479, $1483-90$ (1984).

133. Luna, supra note 71 , at 300.

134. See Garvey, supra note 72, at 314-15 (explaining that apologetic discourse between an offender and his victim can "bring an offender to understand and appreciate the full measure of the damage he has caused ... [and] enable him to overcome mechanisms of defense and denial" and that " $[t]$ he moral education and awakening of the offender that ideally takes place . . is thus the offender's first step on the road to atonement"); Luna, supra note 71 , at 300 ("[T]he presence of the victim and his articulation of the harm he has suffered frustrate an offender's attempt to neutralize the offense.'); Taft, supra note 14, at 1142; infra notes 138-154 and accompanying text.

135. See, e.g., Garvey, supra note 72 , at 314 (explaining that an offender's face-to-face meeting with his victim "brings home to the offender in painful detail the full measure of the injury he has caused" and allows him "to see his victim as a human being with standing equal to his own"); Luna, supra note 71 , at 300 (explaining that an offender's communication of genuine remorse to the victim in a face-to-face conference conveys his "respect for the victim ... and validation of the right not to be victimized").

136. See, e.g., Luna, supra note 71 , at 300 (noting that an offender's communication of genuine remorse to the victim in a face-to-face conference allows the victim to develop "respect for the offender as an individual capable of feeling positive emotions and taking responsibility for his actions"); Pavlick, supra note 120, at 845 ("Apology dispels the perception that the victim is being ignored [and] validates the victim." (citation omitted)); Petrucci, supra note 66, at 343 (noting that a face-to-face interaction "allows the victim to no longer feel shame because the victim sees ... that it is the offender who is responsible for the harmful act, and not the victim").

137. See Garvey, Punishment as Atonement, supra note 9, at 1840 ("[O]nce an offender has done everything possible to atone for his wrong, the burden shifts to the victim to forgive."); Peter H. Rehm \& Denise R. Beatty, Legal Consequences of Apologizing, 1996 J. DISP. RESOL. 115, 116 ("A sincere apology ... can heal humiliation and generate forgiveness."); Taft, supra note 14, at 1142 ("[A]n apology sets in motion a call to the offended, a call for forgiveness.").

138. See, e.g., Jonathan R. Cohen, Advising Clients To Apologize, 72 S. CAL. L. REV. 1009, 1044 (1999) (noting that '[m]any practitioners report that apologies often work 'magic' or "miracles," that "often an apology triggers like conduct from the recipient," and that "even when one is highly skeptical that an apology will 'do any good,' it often does"); Garvey, Shaming Punishments, supra note 9, at 792 (discussing the "almost magical character" of genuine 
stories about the transformative effects of such meetings. Empirical studies and anecdotal evidence from restorative justice programs confirm that faceto-face expressions of remorse and apology matter immensely to offenders and victims. Four empirical studies involving 550 offenders found that $74 \%$ of offenders apologized when given the opportunity to do so in restorativejustice conferences. ${ }^{139}$ By contrast, $71 \%$ of offenders whose only opportunity to apologize came in the courtroom did not do so. ${ }^{140}$ According to these studies, offenders who took part in restorative-justice conferences were 6.9 times more likely to apologize than those who went to court, and victims were 2.6 times more likely to forgive them. ${ }^{141}$ Offenders who have the opportunity to meet with victims often apologize even when they start off vowing not to. ${ }^{142}$ In return, many victims accept the apologies and forgive. ${ }^{143}$ Numerous studies show that a substantial percentage of victims want to meet with offenders. ${ }^{144}$ "The [empirical] evidence suggests that victims see emotional reconciliation to be far more important than material or financial reparation." 145 According to one study, the more that victims are emotionally upset by the offense, the more they want to meet with offenders. $^{146}$

Victims, offenders, and community members who have met and engaged in apologetic discourse overwhelmingly feel satisfied and relieved. Offenders who were interviewed, for example, reported feeling "happy,

apologies); Pavlick, supra note 120, at 846 (observing that the effect of an apology "on the human condition often can be magical").

139. Barton Poulson, A Third Voice: A Review of Empirical Research on the Psychological Outcomes of Restorative Justice, 2003 UTAH L. REV. 167, 189; see also O'Hara \& Yarn, supra note 131, at 1123 ("Wrongdoers often want to be forgiven, and concomitantly, may feel an urge to apologize.").

140. Poulson, supra note 139 , at 189.

141. Id. (describing the differences between restorative-justice and court participants as "consistently large" and statistically significant across all four studies).

142. See Diane Whiteley, The Victim and the Justification of Punishment, CRIM. JUST. ETHICS, Summer/Fall 1998, at 42, 51.

143. Id.

144. Strang \& Sherman, supra note 42 , at $17-23$.

145. Id. at 22; cf. Daniel W. Shuman, The Role of Apology in Tort Law, 83 JuDICATURE 180 , 185 (2000) (noting that in a study of the experiences of victims of sexual assault with civil litigation and government compensation, most of the claimants stated they were pursuing their claim out of a "desire to be heard, have their experience validated, and receive an apology").

146. JoANnA MATtinson \& CATRIONA MiRRLEes-Black, HOME OfFice, RESEARCH STUdy No. 200, AtTITUdes to CRIME AND CRIMINAL JUSTICE: FINDINGS FROM THE 1998 BRITISH CRIME SURVEY 43 (2000), http://www.homeoffice.gov.uk/rds/pdfs/hors200.pdf; see also Deborah L. Levi, Note, The Role of Apology in Mediation, 72 N.Y.U. L. REV. 1165, 1199 (1997) ("[A]pology has proven much more effective in major criminal mediations, where the injury was horribly severe, than in commercial contract cases, where the injury may be regarded as less serious." (footnote omitted)). For an excellent overview and summary of the available evidence on the role of and importance to victims and offenders of apologies in face-to-face meetings, see MARK S. UMBreit et al., RESTORATIVE JUSTICE Dialogue: ANNOTATED BibliogRaPHY OF EMPIRICAL STUDIES ON MEDIATION, CONFERENCING AND CIRCLES (2003), http://2ssw.che.umn.edu/rjp/Resources/Documents/RJAnnotations\%20June\%202003.pdf. 
because all my feelings were out." 147 They "liked being able to apologize" "[t]o let [the victim] know that we are not bad." 148 They "fe[lt] better" because they "knew it was settled," and felt "it was important to tell the victim that the crime was not personal and that [the offender] was sorry.",149 Offenders welcomed the chance to "explain their own behavior, apologize, ease their consciences and reduce feelings of guilt." 150 Victims, likewise, felt they had been given "a chance for healing[,] a chance for informationsharing[,] a chance for building relationships instead of destroying them."151 They explained that "it's a healing-type thing" and that they were able to "get over [their] sense of loss."152

While preliminary studies are encouraging, it is still too early to be sure precisely how these opportunities affect long-term recidivism rates. But empirical studies of restorative justice programs show that they control crime at least as well, if not better than, traditional criminal justice. ${ }^{153}$ And they bring the added benefits of vindicating victims, healing and reconciling victims and offenders, reaffirming social norms, and morally educating offenders and citizens. Though criminal procedure often overlooks these values, they are of fundamental importance to the criminal law. ${ }^{154}$

147. MARK S. UMBREIT, VICTIM MEETS OfFENDER: THE IMPACT OF RESTORATIVE JUSTICE AND MEDIATION 101 (1994) (internal quotation marks omitted).

148. Id. at 104 (internal quotation marks omitted).

149. Caren L. Flaten, Victim-Offender Mediation: Application with Serious Offenses Committed by Juveniles, in ReSTORATIVE JustiCE: InTERNATIONAL PERSPECTIVES 387, 396 (Burt Galaway \& Joe Hudson eds., 1996) (internal quotation marks omitted).

150. Lutz Netzig \& Thomas Trenczek, Restorative Justice as Participation: Theory, Law. Experience and Research, in RESTORATIVE JUSTICE, supra note 149, at 241, 256 (intemal quotation marks omitted).

151. UMBREIT, supra note 147, at 95 (internal quotation marks omitted); see also Poulson, supra note 139, at 189 (noting that offenders' apologies "can have particularly important psychological benefits to ... victims"); Shuman, supra note 145, at 189 ("Although limited, the available theoretical, anecdotal, and empirical evidence all point[s] to the therapeutic potential of apology. Our consistent experience is that apologies are often an important part of the healing process."); Strang \& Sherman, supra note 42, at 33 (reporting research from a restorative justice study showing that the number of victims who felt that participation in a restorative process involving the potential for apologetic discourse with the offender had allowed them to achieve closure and put the crime behind them outweighed those who did not by three to one).

152. Elizabeth Latif, Note, Apologetic Justice: Evaluating Apologies Tailored Toward Legal Solutions, 81 B.U. L. REV. 289, 294 (2001) (quoting UMBREIT, supra note 147, at 95) (internal quotation marks omitted).

153. Strang and Sherman, for example, surveying much of the existing evidence from restorative justice, conclude that restorative justice has always worked either as well as or, in some cases, clearly better than more traditional prosecution methods in controlling repeat offending. See Strang \& Sherman, supra note 42, at 38. They further note that "[t]he evidence to date consistently falsifies," and that "[a]ll of the available evidence contradicts," the notion that an emphasis on restorative processes as opposed to traditional command-and-control measures will lead to more crime. Id. at 38, 41; see also UMBREIT ET AL., supra note 146, at 2-3, 7, 9, 11, 15, 18, $21-22,25,30,32-33,35,38,40-41,44$ (summarizing studies addressing recidivism). Section III.B addresses the recidivism question in more detail.

154. See supra Section I.A. 
Of course, remorse and apology are not panaceas for the problems of crime control and the distress, pain, disrupted relationships, and other effects of crime. Expressing remorse and apologizing can be extremely difficult for offenders for any number of reasons. Tavuchis observes that such expressions can be "as painful and devastating as, if not worse than, any form of physical retribution." offenders are remorseful or willing to turn toward genuine repentance. Not all victims or community members want to hear an apology or meet an offender face to face. ${ }^{157}$ In most cases, victims do not view apologies as substitutes for punishment, as we discuss in Section II.C. ${ }^{158}$ Some apologies are half-hearted or insincere. And when parties do meet, some inevitably come away feeling dissatisfied. ${ }^{159}$ Nonetheless, remorse and apology are more than mere evidence of an offender's true character, or reasons for a sentence reduction, or even creative sanctioning mechanisms. Ideally, they should be integral parts of criminal procedure, serving relational values and not just deterrence and retribution. In fact, even feigned expressions of remorse and apology can serve many of these values, as Section III.F discusses. Viewing remorse and apology through the individual badness model, judges and scholars have been too slow to see how the social value of remorse and apology can further the criminal law's core aims.

\section{Lessons from Noncriminal Contexts: Civil Mediation}

Unlike the criminal law, other areas of law have begun to use remorse and apology in reconciliation rituals. The state's interests are stronger in the

155. TAVUCHIS, supra note 12 , at 35 ; see Pavlick, supra note 120 , at $851-53$ (outlining potential psychological barriers to apology).

156. See, e.g., Taft, supra note 14, at 1142 (noting that apologies can be "difficult, pain-filled, and potentially humiliating"); Levi, supra note 146, at 1181 (observing that apologies can be "acutely susceptible to miscalculation, impasse, uncertainty, and failure to achieve desired ends"); supra note 45 and accompanying text (noting psychological barriers that can obstruct remorse and apology); $c f$. WILLIAM IAN MILLER, FAKING IT 77-90 (2003) (arguing that "faking it" is a ritualized and almost integral part of any real apology).

157. See, e.g., Shuman, supra note 145, at 184 ("Not all victims find apologies soothing and apologies do not respond to all wrongs."); Interview with Paul Engelmayer, Assistant U.S. Attorney, U.S. Attorney's Office for the SDNY, 1989-1994 and 1996-1999, in New York, N.Y. (Mar. 26, 2004) (observing that in cases of financial crimes involving only monetary harm to victims, victims generally "wanted their money back and the defendants in jail and out of their lives"). But see supra notes 144-146 and infra note 298 (citing studies concluding that victims in general view the possibility of emotional reconciliation and healing after a crime as very important).

158. See Robinson, supra note 72, at 381 (observing that few people would think that "justice was done" if "a serious wrongdoer [were] free to skip away to a happy life, even if he genuinely apologized to [his victim]"); infra notes 181-183 and accompanying text.

159. See, e.g., Shuman, supra note 145 , at 185 (noting that sexual assault victims who did not receive an apology "were seriously disappointed"); Taft, supra note 14, at 1141 (stating that a botched apology "can strain relationships or fuel bitter vengeance"). 
criminal than in the civil context, of course, which explains why remorse and apology should not substitute for punishment. But the criminal law could do both, satisfying the state's interest in punishment as well as learning from civil mediation how to serve offenders' and victims' interests. Civil mediation scholarship emphasizes that expressions of remorse and apology can be valuable ways to resolve disputes. ${ }^{160}$ Scholars and commentators in this area stress the need for corresponding legal reforms to facilitate the social and relational benefits of remorse and apology. For example, the rules of evidence may need to exclude some apology-related statements from evidence, and legal education should train law students and lawyers in successful mediation. ${ }^{161}$

Empirical findings support the usefulness of this approach. Victims frequently value genuine expressions of sorrow and contrition more than monetary compensation, ${ }^{162}$ and will often forgo money in the face of such expressions. For example, in one study published in the Journal of the American Medical Association, nearly one-fourth of families who sued their physicians following prenatal injuries reported doing so primarily because their physicians "had failed to be completely honest with them about what happened." "Similarly, in the sexual assault context, researchers have found that "[m]ost [civil] claimants ... were interested in pursuing their claim for therapeutic rather than financial reasons. They identified the desire to be heard, have their experience validated, and receive an apology as important aspects of their therapeutic expectations for the legal

160. See, e.g., Stephen B. Goldberg ET Al., Dispute Resolution: Negotiation, MEDiation AND OTHER PROCESSES 159-60 (3d ed. 1999) (stating that "[t]he first lesson of dispute resolution that many of us learn as children is the importance of apologizing" and going on to explain that an "apology is valuable in repairing whatever harm to the relationship has resulted from the dispute" and that "[m]any mediators have had one or more experiences ... in which an apology was the key to a settlement that might otherwise not have been attainable"); Pavlick, supra note 120; Levi, supra note 146.

161. See, e.g., KATHLEEN M. SCANLON, MEDIATOR'S DESKBOOK 68 (1999) (raising "the possibility of an apology as a component of resolving the dispute" in the checklist of mediator's techniques); O'Hara \& Yam, supra note 131, at 1169-83 (arguing for evidentiary reforms to better realize the value of apology in litigation); Marshall H. Tanick \& Teresa J. Ayling, Alternative Dispute Resolution by Apology: Settlement by Saying "I'm Sorry," HENNEPIN LAW., July-Aug. 1996, at 22, 22 (arguing for proactive use of apology in mediation); see also Cohen, supra note 138, at 1032-36, 1061-63. In light of these developments, several states have amended their evidentiary rules to provide safe harbors for apology. See Aviva Orenstein, Apology Excepted: Incorporating a Feminist Analysis into Evidence Policy Where You Would Least Expect It, $28 \mathrm{SW}$. U. L. REV. 221, 247-48 (1999); Latif, supra note 152, at 301.

162. See supra notes $144-146$.

163. Gerald B. Hickson et al., Factors That Prompted Families To File Medical Malpractice Claims Following Prenatal Injuries, 267 JAMA 1359, 1361 (1992), cited in Jonathan R. Cohen, Apology and Organizations: Exploring an Example from Medical Practice, 27 FORDHAM URB. L.J. 1447, 1458 (2000). 
process." ${ }^{164}$ And in the defamation context, many plaintiffs care more about apologies than money. This is partly because retractions counteract reputational harm, but also partly because refusals to apologize antagonize victims. Many pursue litigation only after publishers rebuff their requests for retractions and apologies. ${ }^{165}$

Developments in mediation practice reflect the trend toward apology. Remorse and apology are increasingly seen as central elements in successful mediation. ${ }^{166}$ The sessions focus "on the parties' interests rather than on their legal position or rights. Parties have the opportunity to tell their story, to explain their needs, and to vent their feelings." ${ }^{167}$ This discourse is designed to foster discussion of moral and interpersonal obligations as well as legal ones. ${ }^{168}$ As Donna Pavlick explains, mediation is "an opportunity to connect face-to-face and engage in interactive negotiation that is beyond purely adversarial behavior." 169 Mediation thus lets parties "confront the substantive... values at the core of their relationship" and provides an "opportunity for the [offender] to apologize and for the victim to forgive." "In other words, mediation encourages the parties to express themselves emotionally and morally. This encouragement, glaringly absent from adversarial litigation, is intensely important in overcoming psychological barriers, allowing defendants to

164. Shuman, supra note 145, at 185 (citing Nathalie Des Rosiers et al., Legal Compensation for Sexual Violence: Therapeutic Consequences and Consequences for the Judicial System, 4 PSYCHOL. PUB. POL'Y \& L. 433 (1998)).

165. Randall P. BeZanson et al., Libel LaW and the Press: Myth and Reality 7994, 159-68, 172, 228-33 (1987) (finding that many plaintiffs would initially be content with apologies but that, after defendants rebuff their requests, many shift to litigation to vindicate and punish); see also id. at 159-68, 172, 228-33 (finding that plaintiffs would consider forgoing litigation if a mediation alternative were open to them but that they sue because they lack alternative avenues of redress); $i d$. at 232 (suggesting that defense lawyers might not naturally support mediation because it cuts against their financial interest).

166. See O'Hara \& Yarn, supra note 131, at 1126 ("Failure to take into account these human tastes for apology and forgiveness can have significant consequences, ... [ [which] have historically garnered little attention from our formal legal system. Recently, proponents of apology and forgiveness, particularly from the alternative dispute resolution (ADR) movement, have urged increased sensitivity to the uses and nuances of these behaviors and their effect on the resolution of disputes.").

167. Pavlick, supra note 120 , at 857.

168. Levi, supra note 146, at 1171 (citing Craig A. McEwan \& Richard J. Maiman, Mediation in Small Claims Court: Consensual Processes and Outcomes, in MEDIATION RESEARCH: THE PROCESS AND EFFECTIVENESS OF THIRD-PARTY INTERVENTION 53, 60 (Kenneth Kressel et al. eds., 1989)).

169. Pavlick, supra note 120 , at 857 . Pavlick goes on to note that "[t]he parties often can settle their differences and effectively resolve the dispute. They can restore the moral balance of power." Id. at 857-58.

170. Id. 
acknowledge legal and moral responsibility, and providing victims with needed moral recompense. ${ }^{171}$

The contrast between civil mediation and criminal litigation could not be more stark. Clearly, these two fields differ significantly, and the parallels are not perfect. Nonetheless, civil mediation's current direction is very different from criminal justice's emphasis on offenders as individuals and its focus on procedural values to the exclusion of substantive concerns. Because routine civil cases are much less about individual blame, retribution, and procedural rights, civil law has found it easier to mine the substantive social value of remorse and apology. ${ }^{172}$

\section{The Practical Import of the Relational Perspective}

Different readers might implement the preceding theoretical discussion in different ways. Most restorative justice enthusiasts, such as Braithwaite, treat remorse and apology as wholesale substitutes for the allegedly cruel, backward instrument of punishment. ${ }^{173}$ In Braithwaite's view, "Restorative justice is most commonly defined by what it is an alternative to," namely the punishment-centered "justice model."174 According to this view,

171. See, e.g., DWIGHT GOLANN, MEDIATING LEGAL DiSPUTES: EFFECTIVE STRATEGIES FOR LAWYERS AND MEDIATORS $\S 7.1$, at 188 (1996); GOLDBERG ET AL., supra note 160, at 159-62; Levi, supra note 146, at 1171; see also JOHN S. MURRAY ET AL., PROCESSES OF DISPUTE RESOLUTION: THE ROLE OF LAWYERS 220-35 (1989) (discussing the importance of psychological and interpersonal variables to successful dispute resolution).

172. This parallel is evident in the reparations context as well, where victims of historical injustices have no clear legal claims against wrongdoers. There, both theoretical and overwhelming practical problems limit reliance on deterrence, retributivism, and individual rights. Apologies thus become an "important form of in-kind reparation" because they "transfer to recipients a valuable intangible benefit, that of moral acknowledgment of historical injustice." Eric A. Posner \& Adrian Vermeule, Reparations for Slavery and Other Historical Injustices, 103 COLUM. L. REV. 689, 729-30 (2003). They also simultaneously help "to remove the stain of moral taint" from the apologizer-often a high-level official speaking on behalf of a country or its institutions-by acknowledging the failure of the apologizer's institutions to prevent the injustice. Id. at 709, 709-10. Expressions of remorse, contrition, and apology are likewise central to truth and reconciliation commissions because of similar practical and theoretical problems with inflicting retribution, deterring, and serving individual rights. See, e.g., Brandon Hamber, Rights and Reasons: Challenges for Truth Recovery in South Africa and Northern Ireland, 26 FORDHAM INT'L L.J. 1074, 1083 (2003) (noting importance of expressions of remorse and apology to addressing consequences of victimhood and promoting truth and reconciliation through the use of formal commissions); Dan Markel, The Justice of Amnesty? Towards a Theory of Retributivism in Recovering States, 49 U. TORONTO L.J. 389, 394-98 (1999) (discussing pragmatic and political problems in the use of criminal prosecutions for violations of human rights committed during apartheid in South Africa); Okechukwu Oko, Confronting Transgressions of Prior Military Regimes: Towards a More Pragmatic Approach, 11 CARDOZO J. INT'L \& COMP. L. 89, 139 (2003) (discussing the importance of expressions of remorse and "genuine contrition on the part of perpetrators" to achieving "reconciliation and forgiveness as a basis for peace and unity" in Nigeria through a proposed truth commission (quoting President Obasanjo of Nigeria)).

173. See supra note 72 and accompanying text.

174. Braithwaite, supra note 70 , at 4 . 
"retribution is in the same category as greed or gluttony," a vice that is "corrosive of human health and relationships." 175 Many proponents view restorative justice as inconsistent with the criminal justice system's assignment of blame because they fear that blame hinders acceptance of responsibility and healing. ${ }^{176}$ Thus, they stress that laypeople should run restorative justice procedures as an alternative to the cold, professionalized, punitive machinery of the criminal justice system. ${ }^{177}$ At most, they argue, criminal punishment should be a fallback for those offenders who refuse to apologize or make restitution. ${ }^{178}$

Many restorative justice programs function in just this way, either by displacing adjudication entirely or by substituting for the tail end of criminal procedure. Vermont, for example, reserves traditional criminal punishment for violent offenders and other felons who are likely to recidivate. A reparative track handles mild to moderately serious crimes, such as burglary, attempted grand larceny, drunk driving, fraud, theft, underage drinking, simple assault, and drug possession. These offenders are adjudicated guilty in the traditional justice system but are not punished. Instead, they enter a reparative program that requires them to make amends, take classes, and write essays on the importance of the law and their crimes. ${ }^{179}$ Salt Lake City diverts misdemeanants with no history of violence to restorative justice programs. If offenders attend classes, pay restitution of no more than $\$ 180$, and listen to victims of other crimes talk about their experiences, prosecutors dismiss their cases. ${ }^{180}$

We do not embrace this dichotomy between apology and punishment because it guts the solemn force of the criminal sanction. At least where the offender has significantly wronged an identifiable victim, excusing him

175. Id. at 7; see also Susan M. Olson \& Albert W. Dzur, Reconstructing Professional Roles in Restorative Justice Programs, 2003 UTAH L. REV. 57, 77 ("'Retributive,' 'punitive,' and 'offender-based' perspectives are seen as in tension with the value of restoration, and it is the job of the restorative justice professional to correct or modify these perspectives . ...").

176. See Olson \& Dzur, supra note 175, at 72 ("Another widely but not universally acknowledged distinction is that restorative justice does not apply to the blame-fixing stage of the criminal justice process." (citing JOHN BRAITHWAITE, RESTORATIVE JUSTICE AND RESPONSIVE REGULATION 35-36 (2002))).

177. Id. at 64 ("Restorative justice theory at times seems to imply little need for professionals at all."); $i d$. at $87,87-88$ (noting that "the idea of de-professionalizing . . . is such a strong element of restorative justice theory," even though in practice program administrators tend to become more professional); $c f$. $i d$. at 76 ("A core value of the traditional criminal justice system that has less resonance in restorative justice is protecting the rights of offenders.").

178. See Braithwaite, Holism, supra note 72, at 404 ("'A] tonement has more power in affirming a just moral order than punishment. But when criminals eschew atonement, punishment- or at least some solemn public condemnation of the crime-is needed to affirm that moral order and to vindicate victims."); see also Olson \& Dzur, supra note 175, at 76 ("If offenders utterly fail to comply with [Salt Lake City's restorative justice program requirements], they are referred back to the court for entry of the conviction and normal sentencing.").

179. Olson \& Dzur, supra note 175 , at 65-68 \& n.30.

180. Id. at 68-71. 
from punishment belittles the crime and the harm. Offenders, victims, and society interpret the failure to punish to mean that the crime is not really wrong and that the offender is free to keep doing it. ${ }^{181}$ As Judge Morris Hoffman fears, restorative justice without punishment becomes "a de facto decriminalization of certain minor offenses which the mavens of the movement do not think should be punished, but which our Puritan ethos commands cannot be ignored." 182 Restorative justice requires no amends to right the imbalanced scales of justice and no bite to underscore society's condemnation of the crime. As Garvey cogently puts it,

Missing from the restorativist agenda ... is the idea of punishment as moral condemnation. ...

... Restorativism cannot achieve the victim's restoration if it refuses to vindicate the victim's worth through punishment. Nor can it restore the offender, who can only atone for his wrong if he willingly submits to punishment. And if neither the victim nor the wrongdoer is restored, then neither is the community of which they are a part. ${ }^{183}$

While most restorative justice programs supplant punishment for some categories of cases, a few have begun to blend mediation and punishment. For example, the University of Wisconsin Law School has begun a restorative justice project that arranges mediation in prison between offenders and victims or their relatives. ${ }^{184}$ During one mediation session, an attempted murderer accepted responsibility, broke down in tears, and hugged his victim, who in turn forgave him. ${ }^{185}$ In another, the mother of a rape and stabbing victim asked to meet with the rapist, who had steadfastly

181. Cf. DuFF, supra note 66 , at $143-55$ (discussing the communicative dimensions of different types of sanctions); MORRIS, supra note 63, at 104 ("Central to punishment of others ... is a communicative act. .. Punishment is deprivatory conduct that means something."); Kahan, supra note 9, at 619-24 (noting that citizens view fines as inadequate punishment for serious offenses because they fail to express condemnation and allow an offender to "buy his way out," pay the fine, and continue to commit crime (internal quotation marks omitted)).

182. Morris B. Hoffman, Therapeutic Jurisprudence, Neo-Rehabilitationism, and Judicial Collectivism: The Least Dangerous Branch Becomes Most Dangerous, 29 FORDHAM URB. L.J. 2063, 2067 (2002).

183. Garvey, Punishment as Atonement, supra note 9, at 1844. As discussed earlier, a few supporters of restorative justice have admitted that punishment might occasionally be necessary for serious crimes or unrepentant offenders. See, e.g., Zehr, supra note 72. Even this concession, however, is not enough. It does not recognize that for most crimes of more than minimal seriousness, punishment is needed to underscore the community's denunciation of the crime and vindication of the victim.

184. See Frank J. Remington Ctr., Restorative Justice Project, http://www.law.wisc.edu/ fjr/restorative/rjpvoc.htm (last visited Sept. 4, 2004). at 9 .

185. Tag Evers, Blessed Are the Peace Makers, IstHMUS (Madison, Wis.), Apr. 10-16, 1998, 
claimed innocence during and after his trial. In the prison-based mediation, he broke down and admitted guilt. ${ }^{186}$ Likewise, the Iowa and Minnesota Departments of Corrections have begun prison-based victim-offender mediation, circles of support and accountability, family team meetings, and victim-impact classes for incarcerated offenders. ${ }^{187}$ Victims can ask offenders why the crime happened, give voice to their wounds, and heal. ${ }^{188}$ To our knowledge, however, this intriguing fusion of mediation and punishment has gone largely unnoticed by the academic literature. ${ }^{189}$

Other scholars, such as Kahan, emphasize using apology as a costeffective shaming sanction. ${ }^{190}$ These scholars say little about the interactive, face-to-face processes of voluntary remorse and apology and the accompanying healing and reconciliation. Instead, their idea is to "magnify the humiliation inherent in conviction" by "communicating the offender's status to a wider audience," "publicly disgrac[ing] the offender," "requir[ing] offenders to publicize their own convictions," or ordering offenders to make public or in-person apologies. ${ }^{191}$ Expressively satisfying shaming sanctions such as public humiliation, denunciation rituals, and forced apologies can deter offenders and denounce crime more cheaply than prison. ${ }^{192}$ Many commentators have pointed out the cruelty of this approach to shaming, and we will not rehash those arguments here. ${ }^{193}$ Our objection

186. Id.

187. Telephone Interview with Bruce Kittle, member of the board of directors of the VictimOffender Mediation Ass'n and chaplain, Iowa Dep't of Corr. Servs. (Feb. 27, 2004); Minn. Dep't of Corr., Sample Restorative Justice Practices in Minnesota, http://www.doc.state.mn.us/ aboutdoc/restorativejustice/rjsamples.htm (last visited Sept. 4, 2004).

188. Iowa Dep't of Corr., History of Victim and Restorative Justice Programs, http://www.doc.state.ia.us/VictimHistory.asp (last visited Sept. 4, 2004).

189. Duff is the one significant exception. He does not examine the features of these programs in great detail, but he does try to integrate the idea of criminal mediation into a normative justification for punishment. See DUFF, supra note 66, at 88-106 (arguing for the increased use of mediation, probation, and community service orders as central to his theory of punishment as a communicative enterprise).

190. See supra note 67 and accompanying text.

191. Kahan, supra note 9, at 631-34; see also Kahan \& Posner, supra note 45 , at 368 ("Shaming is the process by which citizens publicly and self-consciously draw attention to the bad dispositions or actions of an offender, as a way of punishing him for having those dispositions or engaging in those actions.").

192. See Kahan \& Posner, supra note 45, at 368 (arguing that "shaming penalties could prove to be an efficient alternative to prison for white-collar offenders" because they "create strong economic and psychological disincentives against crime, and at only a small fraction of the cost of incarceration"); Skeel, supra note 67, at 1814-15 (arguing that the "moral disapproval" expressed by the "enforcer" through shaming sanctions can "have a chastening effect on actual offenders" and "can also discourage potential offenders from misbehaving in the first instance").

193. See, e.g., ANDREW VON HIRSCH, CENSURE AND SANCTIONS 82-83 (1993) (criticizing shaming penalties as "demeaning rituals" and "attempts to humiliate" that disrespect offenders" human dignity); Garvey, Shaming Punishments, supra note 9, at 759 (noting that "some contemporary shaming penalties do cross - or come close to crossing-the line" of humiliation and dehumanization); Massaro, supra note 68, at 1943 (criticizing shaming punishments in part because they are efforts to "search for and destroy or damage an offender's dignity"). But cf. 
is a different one: By viewing apology as simply a means of humiliation, Kahan and others slight its positive role. ${ }^{194}$ Apology and remorse may be painful, but the main reason for using them is not to inflict pain or satisfy the community's bloodlust. Nor should they serve to ostracize offenders; on the contrary, they are tools for drawing offenders back toward the fold. In Braithwaite's terminology, remorse and apology should be reintegrative shaming sanctions rather than disintegrative ones. ${ }^{195}$ They can heal and strengthen wounded relationships. Remorse and apology are valuable not because pain is good per se, but because they underscore communal norms, reaffirm offenders' moral personalities, and heal victims, offenders, and their communities.

In short, remorse and apology are neither substitutes for punishment nor cruel, ostracizing forms of punishment. Instead, remorse and apology should supplement but not supplant punishment. The values served by remorse and apology should be more integral parts of the process of prosecution and punishment. For the criminal law to regulate society effectively and morally educate, it must serve the values of remorse and apology in addition to deterring crimes, inflicting retribution, and protecting defendants' rights. ${ }^{196}$ Our proposal synthesizes the strengths of restorative justice and Kahan's shaming approach while avoiding their weaknesses. Restorativists demonstrate how remorse and apology can reconcile and heal, while shaming advocates show how remorse and apology can express condemnation of crime and reinforce norms. Each extreme overemphasizes one important piece of the puzzle at the expense of the other.

Currently, however, our criminal justice system is largely a punishment assembly line dominated by prosecutors and defense counsel, in which

James Q. Whitman, What Is Wrong with Inflicting Shame Sanctions?, 107 YALE L.J. 1055, 1059 (1998) (rejecting shaming sanctions not because they are cruel to the offender but because "[ $t]$ hey represent an unacceptable style of governance through their play on public psychology").

194. As Kahan explains, the contrition and apology penalties touted by shaming scholars often "combine stigmatizing publicity with an element of [forced] self-debasement." Kahan, supra note 9 , at 634 . While in some cases the penalties "contemplate genuine rapprochement," in most cases they do not, and "the sincerity of the offenders' remorse seems largely irrelevant." Id.

195. See JoHn BRaithwaITE, CRIME, SHAME AND REINTEGRATION 54-97 (1989); Michael Tonry, Rethinking Unthinkable Punishment Policies in America, 46 UCLA L. REV. 1751, 1763-71 (1999) (criticizing Kahan's embrace of disintegrative shaming punishments). But cf. Dan M. Kahan, Unspeakable Misrepresentations: A Response to Tonry, 46 UCLA L. REV. 1933, 1934-35 (1999) (insisting that his aim is not to sate the public's desires for debasement and degradation and that in fact shaming penalties are less degrading than imprisonment).

196. The two scholars whose approaches come close to ours are Stephen Garvey and R.A. Duff. Garvey, however, focuses on building a theoretical model of punishment that includes some of these concepts. He does not really discuss how to import these ideas into actual criminal procedure and the disposition of cases. See Garvey, Punishment as Atonement, supra note 9, at 1810-29. Similarly, Duff largely restricts his discussion of remorse and apology to their communicative functions in the mediation context as part of his overall theoretical project of justifying punishment as purposive communication. Sec DUFF, supra note 66, at 79-125. 
other actors unfortunately fade into the background. How should remorse and apology change the roles of offenders, victims, and society?

For offenders, we need to move beyond the individual badness model. Remorse and apology should be about much more than simply how much deterrence, incapacitation, and retribution an offender needs. Rather, they are important ways to promote education, expiation, and restoration. Until offenders express remorse or apologize, they often hide behind self-serving denials and distortions. Denial impedes treatment and moral reform, as offenders refuse to admit that they need to change their behavior. It also keeps offenders from acknowledging their moral agency and acting as responsible, law-abiding citizens. Denial and resistance to treatment can thus greatly increase the risk of recidivism. ${ }^{197}$

At the same time, we must not view remorse and apology as helping victims at the expense of offenders. This zero-sum adversarial mentality overlooks how remorse and apology can benefit offenders as well as victims. Offenders who come to terms with their crimes and apologize start on the path to reform. They learn valuable lessons and feel better about themselves as persons. They may thus become less likely to recidivate and are prime candidates for mercy to temper criminal justice. ${ }^{198}$

Victims also need to play a larger role. The relational process of apology gives them much-needed opportunities to achieve catharsis and to learn that the crime was not personal or their fault. ${ }^{199}$ The process needs to allow plenty of points at which victims can participate and benefit from expressions of remorse and apology. Many victims will understandably be reluctant to go through the process for fear of reliving traumatic moments and seeing the offenders again. The criminal justice system should not force victims or offenders to take part, but it should persistently but gently encourage them to do so. For example, mediation programs let victims and offenders bring friends, relatives, victim advocates, or clergy to the mediation. These third parties can allay victims' fears and encourage offenders to make amends. ${ }^{200}$ Mediators reinforce victims' sense of safety and empowerment by soliciting their input on the location, scheduling,

197. See Bibas, supra note 10 , at $1395-96$.

198. See infra note 229 and accompanying text.

199. See FLETCHER, supra note 58, at 248 (endorsing a German proposal to have victims approve all plea bargains, which would require facilitating understanding between victims and offenders, would empower victims, and so might lessen the need for additional victim vindication at a public trial).

200. MARK S. UMBREIT, ThE HANDBOOK OF ViCTIM-OFFENDER MEDIATION 21, 23, 29, 32 (2001); Gordon Bazemore \& Mark Umbreit, A Comparison of Four Restorative Justice Conferencing Models, JUV. JUST. BULL., Feb. 2001, at 1, 6-7. 
layout, and conduct of the mediation. ${ }^{201}$ Apology procedures such as these can help to empower victims and supplement restitution, though they do not supplant it.

Society has a role to play as well. Offenders have wronged society, not just identifiable victims, by disregarding its norms and sowing fear and disorder. Remorse and apology help to affirm communal norms and restore the moral balance. Our criminal justice system should recognize the community's legitimate stake in the process, even if in some cases its role is largely symbolic. Though the primary recipients of apologies and restitution must be victims, the processes of remorse and apology should take place with the encouragement and blessing of the community. ${ }^{202}$ Juries and judges, as voices of the community, should more clearly articulate these functions. ${ }^{203}$

In sum, prosecutors and defense counsel currently dominate criminal procedure and leave little room for remorse or apology. To take these practices seriously, criminal procedure must acknowledge the social, relational dimension of crime and give greater roles to other important actors. It should encourage offenders, victims, and society's representatives to work through the process of apology and reconciliation. The next Part discusses concrete procedural changes that might better achieve these goals.

\section{IMPLEMENTING REMORSE AND APOLOGY}

While some academics have theorized about the benefits of remorse and apology, few have tried to translate theory into practice. At most, scholars and practitioners generally assume that the natural place for remorse and apology is at sentencing. This assumption goes hand in hand with the assumption that remorse and apology are really about the amount of punishment that the individual offender needs. This cramped

201. UMBREIT, supra note 200 , at 21-25. Mediators should also support victims and offenders by using sensitive language, not pushing too hard, and ensuring that the parties participate voluntarily. Id. at 22-27.

202. See Bazemore \& Umbreit, supra note 200, at 6-7 (discussing how sentencing circles empower community representatives by giving them a voice in choosing appropriate sentences); see also id. at 8 (noting that while victim-offender mediation limits the relevant community to these two participants, sentencing circles include as part of the community "anyone with a stake in the resolution of a crime who chooses to participate in the circle"). But see Robert Weisberg, Restorative Justice and the Danger of "Community," 2003 UTAH L. REV. 343, 358-59 (criticizing the "contrived nature of the community setting" as an artifact created by proponents of restorative justice).

203. See Linda Ross Meyer, Forgiveness and Public Trust, 27 FORDHAM URB. L.J. 1515, 1532 (2000) (noting that the jury should serve as the "voice of the community, setting the terms of reintegration" of offenders back into the group); Katie Long, Note, Community Input at Sentencing: Victim's Right or Victim's Revenge?, 75 B.U. L. REV. 187, 227 (1995) (advocating the use of local judges and juries to increase community input through these actors). 
approach ignores the potential for fostering reconciliation throughout the criminal process.

This Part explores how concrete procedures can foster the benefits of remorse and apology at every stage. Section A discusses the early stages of the criminal process, from before arrest to shortly after charging. Section B considers how victim-offender mediation and similar forms of alternative dispute resolution might work for certain types of crimes. These procedures, we argue, can supplement the criminal process and may occasionally supplant it for certain less serious crimes. Section $\mathrm{C}$ addresses the role of cooperating witnesses and the ways that prosecutors can encourage remorse and apology. Section D explores the role of victims' rights throughout the criminal process, including long before sentencing. Section $E$ proposes reforms to plea procedures. Section $F$ suggests reforming sentencing to make it about more than just the individual offender's badness. Finally, Section G considers the costs, difficulties, and tradeoffs that our proposals may involve.

\section{A. At the Beginning of the Criminal Process}

Though the public may think of arrest and charging as automatic events, these decisions involve substantial discretion. Police have wide latitude in deciding whether to arrest an individual and file charges. Likewise, prosecutors can choose whether to accept police officers' recommendations and pursue those charges. Particularly for lower-level crimes, police may not arrest and prosecutors may decline to charge or may divert cases for alternative resolution after charging. ${ }^{204}$

Remorse and apology could play a much larger role in these decisions. Moving in this direction would not require changing existing law; police and prosecutors would simply have to use their existing discretion with an eye toward encouraging remorse and apology. While some probably use their discretion in this way already, there is room to do more. Of course, a simple apology is no substitute for arrest and prosecution of a crime of violence. But the bulk of crimes are relatively minor, including petty thefts and vandalism. ${ }^{205}$ In these cases, informal resolution may resolve cases

204. See, e.g., MONT. CODE ANN. $\S 46-16-130$ (2003) (authorizing deferred prosecution before or after the filing of charges, with possible dismissal of charges, except for driving while impaired); WASH. REV. CODE § 9.94A.411 (2004) (authorizing prosecutors to decline to prosecute for a variety of reasons, including a request of the victim, particularly for minor assaults and nonviolent property crimes that result in no major loss).

205. BuREAu OF JUSTICE STATISTICS, DEP'T OF JUSTICE, NCJ 203301, SOURCEBOOK OF CRIMINAL JUSTICE STATISTICS, 2002, at 188 tbl.3.1 (2002), available at http://www.albany.edu/sourcebook/ (reporting that in 2001, there were more than three times as many property crimes as crimes against the person and that $77 \%$ of these property crimes were 
better than arrest and prosecution. By forgoing arrest or delaying it pending restitution and amends, the system can promote face-to-face interaction between offenders and victims. ${ }^{206}$ In appropriate cases, the result may be apology and reconciliation. Offenders may better appreciate the wrongfulness of their acts, while victims may find the swift apology satisfying. And by bringing in parents or other authority figures, the law can reinforce the moral authority of its pronouncements and the need for remorse, reform, and apology. ${ }^{207}$

Even after arrest, prosecutors may decline to prosecute if a low-level offender expresses remorse and makes restitution or amends. Prosecutors can use the threat of charges as leverage by deferring prosecution or diverting cases to alternative forums, ultimately dismissing the charges if offenders apologize and make amends. Pretrial diversion programs, of course, are already well established in many jurisdictions. ${ }^{208}$ Expressions of apology and contrition, moreover, often play significant roles in individual prosecutors' decisions to make these alternative dispositions available to offenders. $^{209}$ But prosecutors still use such programs sporadically and

thefts or attempted thefts, of which $67 \%$ involved completed thefts of less than $\$ 250$ ); id. at 451 tbl.4.6 (reporting 8933 murders and nonnegligent manslaughters, 17,394 forcible rapes, and 69,405 robberies in 2002 , compared with 729,825 larcenies, 362,979 cases of drunkenness, 398,728 cases of disorderly conduct, 169,842 cases of vandalism, and 51,275 cases of prostitution and commercialized vice).

206. Requiring restitution and amends may promote the face-to-face interaction that leads to apology, though restitution is no substitute for apology. Deborah Levi relates the following example of one such use of remorse and apology:

[I]n one case of reighborhood vandalism, nine families became involved in restoring damage done to the victim's home. Each child involved apologized to the homeowner and explained the details of the damage he had caused. Then each child paid twentyeight dollars that he, not his parents, earned in order to pay for repairs. Lastly, each child promised not to retaliate against the homeowner's son.

... The payments reimbursed the victim for the damage...; the promises restored the homeowner's sense of security in the neighborhood; and the apology vindicated the homeowner's sense of moral indignation while his forgiveness reconciled the neighbors.

Levi, supra note 146, at 1202 (footnote omitted).

207. See Luna, supra note 71 , at 300 ("[T] he presence of the young person's family, their personal condemnation of the offense, and the visible signs of anguish felt by family members confronted by the harm caused by their own kin all provide exceptionally powerful signals to the juvenile on the wrongfulness of his conduct.").

208. See, e.g., N.Y. CRIM. PROC. LAW $\S 170.40$ (McKinney 2004) (providing for the dismissal of a prosecutor's information or a misdemeanor complaint in the interests of justice); $i d$. $\S 170.55$ (providing for the adjournment of crimiral charges in contemplation of dismissal); DEP'T OF JUSTICE, UNITED STATES ATTORNEYS' MANUAL $\S 9-22.000$ (1997) (providing for the possibility of pretrial diversion for certain crimes).

209. See, e.g., N.Y. CRIM. PROC. LAW $\$ 170.40(1)(d)$ (McKinney 2004) (directing the court to consider, among other things, "the history, character and condition of the defendant" in ruling on a motion to dismiss in the interests of justice); DEP'T OF JUSTICE, supra note $208, \S 9-22.100$ (leaving solely to the discretion of the U.S. Attorney the decision whether to "divert any individual against whom a prosecutable case exists," so long as the individual is not charged with certain specified offenses); Interview with Paul Engelmayer, supra note 157 (characterizing 
inconsistently, with great variation among jurisdictions. ${ }^{210}$ This is particularly true when it comes to institutionalizing prosecutorial efforts to facilitate direct, interactive expressions of remorse and apology through diversion. Unlike traditional restorative justice enthusiasts, ${ }^{211}$ we do not see remorse and apology as wholesale substitutes for criminal punishment. But in appropriate minor cases, expressions of remorse, apology, and perhaps promises of restitution may suffice.

The biggest objection to this proposal is that discretion allows police and prosecutors to discriminate, consciously or unconsciously, based on race and other characteristics. This risk of discrimination is especially troubling because race, sex, and class may color assessments of remorse and apology. ${ }^{212}$ While this risk of discrimination is real and pervasive, it is already inherent in existing prosecutorial and police discretion. Indeed, a deliberate focus on remorse and apology might help to structure this discretion, making it less susceptible to arbitrariness and discrimination. Prosecutors might promulgate written policies that spell out criteria for declining or diverting minor cases in which offenders apologize and begin to make amends. No law can eradicate all danger of discrimination, but policies that are sensitive to this danger can reduce its risk.

\section{B. Victim-Offender Mediation and Similar Mechanisms}

In the last few decades, communities have experimented with various voluntary, nonadversarial processes for bringing offenders, crime victims, and others together. Victim-offender mediation brings offenders (especially juveniles) and victims face to face. ${ }^{213}$ Community reparative boards allow panels of trained citizens to discuss crimes with offenders and agree on restitution plans. ${ }^{214}$ Family group conferences bring together the families of

\footnotetext{
"admission of wrongdoing and remorse" as "conditions" to the use of diversionary programs); Interview with Peter Vigeland, Assistant Dist. Attorney, Manhattan Dist. Attorney's Office, 19801984, in New York, N.Y. (Mar. 26, 2004) (noting that "expressions of contrition certainly helped" in local prosecutors' eyes when considering whether to move for an adjournment in contemplation of dismissal under section 170.40 of New York's Criminal Procedure Law).

210. See, e.g., Thomas E. Ulrich, Pretrial Diversion in the Federal Court System, FeD. PROBATION, Dec. 2002, at 30, 34 (noting that while a handful of federal districts diverted $30 \%$ or more of their total pretrial supervision caseloads between 1995 and 1999, there was wide variation and other districts diverted only $2 \%$ of their pretrial supervision cases). We recognize that the more leverage the system employs to press for remorse and apology, the greater the danger that these expressions will be insincere. We discuss this issue infra Section III.F. We also recognize that any benefits tied to making amends must take into account the offender's means. In other words, a poor offender who credibly commits to make restitution should not suffer simply because he lacks the wealth to pay restitution immediately.
}

211. See supra notes 173-183 and accompanying text.

212. See supra note 77 and accompanying text.

213. Bazemore \& Umbreit, supra note 200 , at 2.

214. Id. at 3 . 
offenders and victims to discuss crimes, mediated by a trained facilitator. ${ }^{215}$ Sentencing circles allow victims, offenders, the friends and family of both, community members, and justice professionals to deliberate and agree upon a sentence. ${ }^{216}$ While these four models differ slightly, each lets victims explain how crimes affected them, ask questions, develop restitution plans, seek apologies, and air their sorrows. In turn, offenders learn about their victims' sufferings; ideally, apologize and commit to making amends; and heal the guilt that might otherwise plague their conscience. ${ }^{217}$ Many programs also incorporate victims' and offenders' family and friends, to provide support, encouragement, and oversight as offenders commit to change. Victims can more easily express their pain and anger with loved ones at their sides. Offenders are skilled at denying or minimizing their crimes, but the tears of their parents or siblings can pierce these denials and drive home the need for change. ${ }^{218}$

These nascent mechanisms can be quite successful. A meta-analysis of empirical studies found that victim-offender mediation and family conferencing (hereinafter "mediation") was consistently more successful than traditional criminal justice in a variety of ways: $82 \%$ of victims whose cases were handled in mediation believed that the criminal justice system was fair, versus $56 \%$ of those in court. ${ }^{219}$ Likewise, $91 \%$ of offenders whose cases were handled in mediation thought the criminal justice system was fair, versus $78 \%$ of those in court. ${ }^{220}$ The same meta-analysis found that $78 \%$ of victims in mediation were satisfied with the handling of their cases,

215. Id. at 5 .

216. Id. at 6.

217. Duff explains the basic criminal mediation process this way:

Part of the point of the criminal mediation process consists ... in th[e] exchange of explanations. The victim can explain her suffering to the offender... in [a way] that expresses and tries to communicate ... her hurt and anger, and that condemns the crime as a wrong. She will also have a chance to come to understand (which will not be to condone) the offender's action from his perspective. The offender will be vividly confronted, through his victim's voice, with his crime. But he will also have a chance to explain himself.

DUFF, supra note 66, at 93.

218. See Braithwaite, supra note 70, at $47-49$ (noting that offenders frequently deny that there was a victim, that the victim suffered injury, that they were responsible for their actions, that their actions were blameworthy, or that the victim was in the right, and noting that, while offenders may deflect shame from themselves, seeing the shame of their loved ones at their deeds may spur them to discuss their responsibility or change their ways).

219. Poulson, supra note 139, at 179-80 tbl.1 \& fig.1 (relying on four studies of victims). One potential confounding factor in all of these studies is that all parties must consent to mediation. The cases of those victims or offenders who decline mediation and choose to go to court may differ systematically from the cases that enter mediation; for example, the mediation participants may be more optimistic and less bitter. Thus, the sample of cases in which all parties consent to mediate may be skewed towards those who are already receptive to it and its benefits.

220. Id. (relying on five studies of offenders). 
versus $56 \%$ of victims in traditional court proceedings. ${ }^{221}$ Likewise, $84 \%$ of offenders in mediation were satisfied with the handling of their cases, versus $73 \%$ of offenders in court. ${ }^{222}$ Those in mediation are more likely to have a chance to tell their stories $(94 \%$ versus $64 \%$ of victims, and $88 \%$ versus $64 \%$ of offenders). ${ }^{223}$ They are also more likely to feel that their opinions were adequately considered ( $94 \%$ versus $92 \%$ of victims, and $72 \%$ versus $55 \%$ of offenders). ${ }^{224}$ They are more likely to feel that the judge or mediator was fair in their particular case $(88 \%$ versus $76 \%$ of victims, and $91 \%$ versus $63 \%$ of offenders). ${ }^{225}$ Those in mediation are more likely to feel that the outcome was fair and satisfactory ( $73 \%$ versus $54 \%$ of victims, and $77 \%$ versus $67 \%$ of offenders). ${ }^{226}$ They are also more likely to believe that the offender was held accountable (92\% versus $71 \%$ of victims, and $82 \%$ versus $49 \%$ of offenders). ${ }^{227}$ In mediation, offenders are more likely to apologize ( $74 \%$ versus $29 \%$ ), victims are more likely to forgive $(43 \%$ versus $22 \%$ ), and victims are less likely to remain upset (28\% versus $57 \%$ ) or fear revictimization ( $15 \%$ versus $34 \%)^{228}$

Finally, and most importantly, mediation seems to reduce recidivism. A meta-analysis of fifteen studies found that juvenile offenders who take part in mediation recidivate up to $26 \%$ less than those who go to court. ${ }^{229}$ When juvenile offenders do recidivate after mediation, they commit less severe offenses than adjudicated juveniles do. ${ }^{230}$ Another meta-analysis found that in seven out of seven randomized field trials, restorative justice worked at least as well as adjudication at preventing recidivism. Two of the seven

221. Id. at 181-82 tbl.2 \& fig.2 (relying on six studies of victims).

222. $I d$. (relying on five studies of offenders).

223. Id. at 183-84 tbl.3 \& fig.3 (relying on one study of victims and two studies of offenders).

224. $I d$. at 185 tbl.4 \& fig.4 (relying on one study of victims and one study of offenders).

225. Id. at 186-87 tbl.5 \& fig.5 (relying on one study of victims and two studies of offenders).

226. Id. at 193 tbl.9 \& fig.9 (relying on one study of victims and offenders).

227. Id at $188-89$ tbl.6 \& fig.6 (relying on two studies of victims and two studies of offenders).

228. Id. at 190-91 tbl.7 \& fig.7 (relying, for apology and forgiveness statistics, on one study of victims and four studies of offenders); id. at 196-98 tbls.11-12 \& figs.11-12 (relying, for upsetvictim statistics, on two studies and, for fear-of-revictimization statistics, on four studies); see Strang \& Sherman, supra note 42 , at $29-30$ figs. $2-3$, 40 fig. 12 (finding that $72 \%$ of victims received apologies in conferences, compared with $19 \%$ of victims in court; that $5 \%$ of victims in conferences feared revictimization by the offender, compared with $18 \%$ of those in court; and that the percentage of victims who feared offenders dropped from $20 \%$ before conferences to $9 \%$ afterwards).

229. Victim-offender mediation "participation is associated with a reduction in delinquent behavior," particularly if one defines delinquency to mean commission of the same offense again. William R. Nugent et al., Participation in Victim-Offender Mediation and the Prevalence and Severity of Subsequent Delinquent Behavior: A Meta-Analysis, 2003 UTAH L. REV. 137, 164. "In terms of effect size, the reduction in reoffense may be as great as $26 \%$ relative to non-VOM participants." Id. at 162.

230. Id at $160-61,164$ (finding that this reduction was large and statistically significant, but cautioning that few of the studies had addressed the severity of reoffense issue). 
trials found that it clearly reduced recidivism. ${ }^{231}$ Other studies confirm that mediation participants are less likely to recidivate and that, when they do recidivate, they commit less serious offenses. ${ }^{232}$ One must read the data cautiously, because many of these studies focused on juveniles and because some studies found no significant effects. Even so, the results are promising. On the whole, these programs seem to leave both victims and offenders more satisfied and better off.

Thus, the law ought to make mediation more widely available. From arrest to incarceration, both parties should have easy access to and notice of victim-offender mediation, so they can use it whenever the time is right. ${ }^{233}$ The court system should supply trained mediators free of charge. Stenographers would transcribe the mediation so that judges could later use the transcripts at sentencing. ${ }^{234}$ The mediation would be at a time and place most convenient and comfortable to everyone involved. It need not take place in a courthouse or during business hours, but could be in a school, church, or home in the evening or on a weekend. ${ }^{235}$ Offenders would suffer no penalty for remaining silent or refusing to mediate. They could, however, choose to show judges at sentencing that they had apologized and begun to reform.

Each side could engage in as much or as little mediation as it liked. In some cases, of course, a traumatized victim or stubborn offender would refuse entirely. Thus, victims of sex crimes or violence might often be afraid or unwilling to take part. Interestingly, however, mediation seems to work even better to reduce violent crimes than property crimes. ${ }^{236}$ Perhaps the stronger emotions in these cases produce more powerful remorse and empathy, which in turn may reduce recidivism. ${ }^{237} \mathrm{~A}$ mugging victim, for

231. Strang \& Sherman, supra note 42 , at $38-39$.

232. UMBREIT, supra note 200, at 171-73 (summarizing the results of several English studies of mediation involving adults, as well as the more numerous mediation programs for youths).

233. Some jurisdictions are already moving in this direction. See supra text accompanying notes 184-188.

234. One could imagine also making the transcripts available to juries, but this might encourage self-serving statements or silence in cases that might head to trial. One might also condition admissibility on the consent of the parties, at least at the guilt stage. Otherwise, defense lawyers might have to advise their clients to remain silent lest they hurt their cases and prejudice their Fifth Amendment rights. Unless all parties consented, the transcripts could remain sealed and confidential. $C f$. FED. R. EvID. 408 (making settlement offers and discussions inadmissible "to prove liability for or invalidity of the claim or its amount," except when the statement is being used for another purpose).

235. See Luna, supra note 71, at 299.

236. See Strang \& Sherman, supra note 42 , at 40.

237. Id.; see also, e.g., Ralph Blumenthal, Victim's Son Is Given Award for Forgiving Father's Murder, N.Y. TIMES, Oct. 23, 2003, at A26 (reporting that death row inmates banded together to award a scholarship to a son who forgave his father's murderer); Cheryl Wetzstein, Restorative Justice Lets Inmates Make Peace with Victims; Bible-Based Program Wins Converts, WASH. TIMES, Mar. 9, 1999, at A2 (noting forceful speeches in favor of restorative justice by the 
example, might be anxious to learn why the mugger targeted her and be relieved to learn that she was only a random target. But because violent offenders and victims of violence may be reluctant, mediation may happen most often for nonviolent property crimes. And as our description implies, mediation should supplement but not supplant the criminal process. Mediation should be not a soft escape from or alternative to punishment, but an adjunct. The outcome of mediation might influence sentencing judges, as Section $F$ discusses, but it should not preempt sentencing entirely.

The biggest danger here might be forcing reluctant offenders and victims into mediation. While most victims like and are satisfied with mediation, a significant minority (perhaps a quarter to a third) are not. ${ }^{238}$ The decision to mediate ought to be voluntary; while persuasion and inducement are appropriate, coercion is not. Officials must judiciously respect offenders' and victims' free choices not to participate, whether out of self-interest, fear, or anger. Thus, parties should suffer no penalties for refusing to mediate. There would still be some equality concerns, as when offenders lose the possible benefits of mediation because victims refuse to take part, but this risk is a tolerable one.

\section{Cooperating Witnesses}

Prosecutors frequently convince offenders to flip and become cooperating witnesses. Cooperators often tape-record conversations, provide information, and testify against their former co-conspirators and associates. Frequently, witnesses and lawyers treat cooperation agreements strictly as business arrangements, in which cooperators help with investigations and testimony in exchange for reduced sentences or money. ${ }^{239}$ This mercenary approach leads to worries about the truthfulness of cooperators' testimony; the fear is that they will lie or embellish to please prosecutors and earn rewards. ${ }^{240}$

Prosecutors, however, can use their existing discretion differently. When persuading offenders to cooperate, they can emphasize that offenders

mother of one murder victim and the wife of another murder victim, whose daughter was also raped).

238. See Braithwaite, supra note 70 , at 21-22 (collecting statistics on victim satisfaction of restorative justice programs).

239. See Simons, supra note 24 , at 22-26 (explaining the utilitarian model of cooperation).

240. See, e.g., Symposium, The Cooperating Witness Conundrum: Is Justice Obtainable?, 23 CARDOZO L. REV. 747 (2002); Daniel C. Richman, Cooperating Defendants: The Costs and Benefits of Purchasing Information from Scoundrels, 8 FED. SENTENCING REP. 292 (1996); Ellen Yaroshefsky, Cooperation with Federal Prosecutors: Experiences of Truth Telling and Embellishment, 68 FORDHAM L. REV. 917 (1999). 
have committed shameful deeds and must right their wrongs. ${ }^{241}$ One powerful sales pitch is to stress making amends by joining the good guys with the white hats- "Team America," as one prominent former federal prosecutor called it. ${ }^{242}$ Put another way, prosecutors can do much to emphasize the moral side of cooperation. Though offenders have acted badly, many still know at some level that they ought to be ashamed and recognize a need to atone. The most powerful way to undo a wrong is not only to renounce it, but to help bring it to justice. Repenting, apologizing, and making amends are important components of cooperation. ${ }^{243}$ These very elements show up in the written cooperation agreements that prosecutors and cooperators make. Cooperation agreements often require cooperators to admit guilt, plead guilty (to every crime committed, in some districts), tell no lies, and make restitution. ${ }^{244}$

These actions not only help cooperators to expiate their crimes, but also bring valuable practical benefits. They break down cooperators' selfidentification with the criminal element and strengthen moral norms. The moral dimension reinforces the practical rewards for providing candid and complete information. Crawling out of the web of lies and crime can be morally satisfying, counteracting to some extent the temptation to concoct false testimony. The moral transformation may make offenders humbler, readier to admit their wrongs, and so more credible to juries. ${ }^{245}$ Thus, their testimony may be more compelling, adding a practical benefit to the psychic rewards of morality for its own sake. ${ }^{246}$

Once again, this use of prosecutorial discretion raises the dangers of discrimination and abuse of power. But these dangers are inherent in existing prosecutorial discretion; remorse and apology make them no worse. On the contrary, by guiding prosecutorial decisions, remorse and apology may make these decisions more consistent and fair.

241. As Erik Luna puts it, "[G]enuine remorse is a prerequisite to the moral development of the offender. Without understanding the impropriety of his conduct, he may retain a deviant identity and connection to an antisocial subculture." Luna, supra note 71, at 294.

242. Katyal, supra note 41, at 1356 n.186 (quoting Mary Jo White, former U.S. Attorney for the SDNY).

243. Simons, supra note 24, at 41 (following Garvey, Punishment as Atonement, supra note 9 , at 1810-29).

244. See Yaroshefsky, supra note 240 , at 953 (reporting that if cooperators lie, they risk having prosecutors "rip[] up their cooperation agreement[s]" and losing their bargains). The point in the text also accords with the first author's experience as a federal prosecutor.

245. One former federal prosecutor explained to one of us in an interview that "obviously remorseful" cooperators, in his experience, were "much more likely to be effective witnesses" because their testimony seemed to juries "much less mechanical and less calculated" and they appeared much more "affected by what they had done." Interview with Paul Engelmayer, supra note 157.

246. Simons, supra note 24 , at $49-50$. 


\section{Extending Victims' Rights}

Currently, a criminal case is a duel between the state and the defendant. Victims are often interviewed and called to testify, and sometimes they even have a right to make a statement at sentencing. Fundamentally, however, their role is minor and reactive. Police and prosecutors run the show; victims lose control when they are victimized and again when their cases disappear into the criminal justice system. Often, they do not even learn that an offender has been charged, offered a plea bargain, convicted at trial, or sentenced, or they learn these things long after the fact. ${ }^{247}$

There is an extensive literature debating the pros and cons of victims' rights, and we do not want to wade into that broader debate here. Victims' bills of rights often guarantee victims fair treatment, protection from the accused, restitution, notice of court proceedings and outcomes, and attendance at court proceedings. ${ }^{248}$ Nothing in our proposals would abridge these rights. Victims would not have to enter mediation, for example, particularly if they felt threatened or uncomfortable. Our point is simply that victims now have no structured opportunity to meet with defendants, express forgiveness, and heal. This hurts both parties. Many states do allow victims to speak at sentencing, but as noted earlier, sentencing is not structured to allow direct, open interaction. At sentencing both victim and defendant face forward and speak to the judge. For the defendant to face the victim, he would literally have to turn his back on the judge. ${ }^{249}$ Moreover, sentencing frequently is a drama scripted by lawyers for the benefit of a judge rather than an opportunity to speak from the heart.

Our approach tries to transcend the criticism that victims' rights measures must be vengeful and anti-defendant. Currently, the most that a victim might do is to argue for a stiff sentence. This focus regrettably turns victims' rights into a zero-sum game, as if the only way to make victims happy is to impose stiffer punishments at the expense of offenders. Victims'

247. See, e.g., Douglas E. Beloof, Victims in Criminal Procedure 21-23 (1999) (discussing victims' alienation from the criminal justice process); TOBOLOWSKY, supra note 42, at 36-38 (discussing the continued problems faced by victims in receiving notification of important proceedings and outcomes in their cases). Prosecutors sometimes consult with victims' families in deciding whether to seek the death penalty, though even here consultation may be sporadic or even limited to the families of victims who are white. See PREJEAN, supra note 17, at

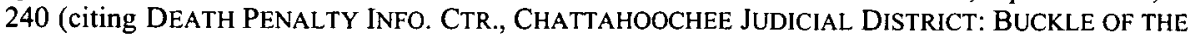
DEATH BELT: THE DEATH PENALTY IN MICROCOSM (1991), at "Victims' Families: A Contrast in Black and White," available at http://www.deathpenaltyinfo.org/article.php?scid=45\&did=540).

248. See, e.g., 42 U.S.C. $§ 10606$ (b) (2000); see also Beloof, supra note 31 , at 289 \& n.2, 294 \& n.29 (noting that the vast majority of states enshrine victims: rights in their constitutions or statutes and that these rights typically guarantee fairness, dignity, and respect by giving victims notice, the right to attend, and the right to speak with prosecutors and judges, and that they sometimes also include rights to privacy and protection).

249. See supra note 53 and accompanying text. 
rights to participate could be more constructive, however. Studies suggest that most victims are far less vengeful and punitive than most lawyers assume. ${ }^{250}$ Empirical research finds that victims criticize the criminal justice system not because it is too lenient but because they have few rights and play little role in the process. ${ }^{251}$

Victims do not want vengeance so much as additional rights to participate. First, and above all else, they would like information about their cases. $^{252}$ In one survey, more than four-fifths of victims thought it very important to receive information about arrests, grand jury proceedings, bail, and release dates. ${ }^{253}$ While $83 \%$ of people surveyed considered it very important for victims to be informed, officials tell few victims of arrests, and only $42 \%$ of those victims are kept informed of police investigations. ${ }^{254}$ Even those who learn of a suspect's arrest rarely receive notice of most further proceedings. ${ }^{255}$ Nor do many receive notice of their rights to make statements and discuss cases with prosecutors. ${ }^{256}$

250. See Lucia Zedner, Victims, in ThE OXFORD HANDBOOK OF CRIMINOLOGY 419, 443-44 (Mike Maguire et al. eds., 2002).

251. See Bharat B. Das, Victims In THE CRIMINal Justice SyStem 126-27, 131 (1997); JO-ANNE M. WEMMERS, VICTIMS IN THE CRIMINAL JUSTICE SYSTEM 19, 207-08 (1996); Joanna Shapland, Victims and the Criminal Justice System, in From CRIME POLICY TO VICTIM POLICY: REORIENTING THE JUSTICE SYSTEM 210, 213 (Ezzat A. Fattah ed., 1986); Strang \& Sherman, supra note 42 , at $18-25$.

252. See WEMMERS, supra note 251 , at 19 ("The informational needs of victims are often identified as the most common need of all victims."); Strang \& Sherman, supra note 42 , at 20 ("Victims repeatedly say that one of the greatest sources of frustration to them is the difficulty in finding out from criminal justice authorities about developments in their cases. Indeed, some victims have said that is all they want from the justice system and would be satisfied simply to achieve that goal." (footnote omitted)).

253. DeAN G. Kilpatrick ET AL., THE Rights OF CRIME Victims-Does Legal Protection MAKe a DifFERENCE? 4 (Nat'l Inst. of Justice, Research in Brief, NCJ 173839, 1998), available at http://ncjrs.org/pdffiles/173839.pdf.

254. JoHn M. BOYLE, COUNCIL OF STATE GOV'TS/E. REG'L CONFERENCE, CRIME ISSUES IN THE NORTHEAST 3 (1999), available at http://www.csgeast.org/pdfs/cv.project.report.pdf (giving data from 1998 survey of over 4000 members of the public in nine Northeastern states); see also Council of State Gov'ts/E. Reg'l Conference, Sentencing Policy and Victims' Rights, http://www.csgeast.org/crimrights.asp (last visited Sept. 4, 2004) (containing data set for survey).

255. DAS, supra note 251, at 126-27, 131; KILPATRICK ET AL., supra note 253, at 4 exhibit 1 (reporting that bond-hearing notification rates are approximately $42 \%$ to $63 \%$, bail notification rates are approximately $26 \%$ to $38 \%$, sentencing-hearing notification rates are about $30 \%$ to $56 \%$, parole-hearing notification rates are $35 \%$ to $70 \%$, plea-negotiation notification rates are $53 \%$ to $58 \%$, and charge-disinissal notification rates are $39 \%$ to $42 \%$, and noting that, in each case, the lower figure is the rate in states with weak victims' rights laws and the higher figure is the rate in states with strong victims' rights laws).

256. KILPATRICK. ET AL., supra note 253, at 5 exhibit 2 (reporting that victims are notified of the following rights at the following rates: $47 \%$ to $71 \%$ are told that victim services are available, $41 \%$ to $70 \%$ are told of their right to discuss their cases with the prosecutor, $42 \%$ to $72 \%$ are told of their right to make victim-impact statements, and $36 \%$ to $62 \%$ are told of their right to make victim-impact statements at parole hearings, and noting that, in each case, the lower figure is the rate in states with weak victims' rights laws and the higher figure is the rate in states with strong victims' rights laws). 
Second, many victims want to participate in their cases beyond simply testifying as witnesses. ${ }^{257}$ More than $75 \%$ of victims in the survey just mentioned thought it very important to be involved or heard in bail hearings, dismissals of charges, plea discussions, parole hearings, and sentencings. ${ }^{258}$ "[A]lthough victims' desire is to be included in the criminal justice process, they have no desire to take control of the case."259 Rather, simply by taking part, victims begin to recover emotionally, counteracting the alienation and powerlessness they may feel. ${ }^{260}$

Third, victims value emotional healing and apology. ${ }^{261}$ Most victims want to tell offenders how their crimes affected them and hear offenders answer their questions about the offense. ${ }^{262}$ Confronting the offender in person is an important component of this emotional interaction. One victim who went through mediation said, "I liked that the kid had to look me in the eyes." 263 Another said, "I guess being able to meet him face to face and realize that he was just a kid who made a mistake was what I liked the most." 264 Face-to-face mediation reassures victims, greatly reducing their fears that the offender will victimize them again. ${ }^{265}$ Victims want face-toface apologies so that they can understand why their crimes happened to them, release their anger, and regain a sense of control and self-esteem. ${ }^{266}$ When offenders accept responsibility, express remorse, and apologize, victims can more easily heal, reconcile, and forgive. ${ }^{267}$

Fourth, victims often desire monetary restitution. ${ }^{268}$ While victims' rights laws purport to guarantee it, fewer than twenty percent of victims in fact receive any restitution. ${ }^{269}$ Typically, the problem is not that defendants

257. JoANNA ShaPland ET AL., ViCTIMS IN THE CRIMINAL JUSTICE SySTEM 176-78 (1985); Strang \& Sherman, supra note 42, at 21-22.

258. KILPATRICK ET AL., supra note 253, at 4.

259. WEMMERS, supra note 251 , at 208.

260. Strang \& Sherman, supra note 42 , at 21.

261. HEATHER StRANG, REPAIR OR REVENGE: ViCTIMS AND RESTORATIVE JuSTICE 88-118 (2002); Strang \& Sherman, supra note 42 , at 22-23.

262. UMBREIT, supra note 200, at 165, 188; Mark S. Umbreit, Mediating Victim-Offender Conflict: From Single-Site to Multi-Site Analysis in the U.S., in RESTORATIVE JUSTICE ON TRIAL: PITFALLS AND POTENTIALS OF VICTIM-OFFENDER MEDIATION: INTERNATIONAL RESEARCH PERSPECTIVES 431, 433 tbl.1 (Heinz Messmer \& Hans-Uwe Otto eds., 1991) (noting that ninetytwo percent of victims who went through mediation thought that telling offenders about their crimes and hearing offenders answer their questions was important, far more than the seventy-six percent who emphasized their desire for financial compensation).

263. Umbreit, supra note 262 , at 433.

264. Id.

265. UMBREIT, supra note 200 , at 189.

266. Petrucci, supra note 66, at 351-52, 354-56.

267. See Marilyn R. McNamara \& Mandeep K. Dhami, The Role of Apology in Restorative Justice 6-7, 9 (June 1-4, 2003), http://www.sfu.ca/cfrj/fulltext/mcnamara.pdf.

268. Strang \& Sherman, supra note 42 , at 23-24.

269. KILPATRICK ET AL., supra note 253, at 6. 
are poor, but that officials know little about the right to restitution, victims' economic losses, or defendants' assets. ${ }^{270}$

Finally, victims want procedural fairness and respect. ${ }^{271}$ This sense of fairness depends more on authorities' efforts to include victims in the process than on case outcomes. ${ }^{272}$ Victims may complain, for example, that police seemed unhelpful or unsympathetic. ${ }^{273}$

Except for restitution, these benefits come at little material cost to offenders. True, offenders may find apologizing uncomfortable, but apologies may cleanse their consciences as well as heal and reconcile victims. These various goods that victims want reinforce one another. The more victims can follow their cases and have procedural opportunities to interact with offenders, the more openings for remorse and apology there are. And the more remorse and apology they receive, the more victims feel respected and the more likely they may be to receive restitution (pursuant to a mediation agreement).

To promote remorse and apology, criminal procedure should let victims participate more actively in all parts of the criminal process and apprise them of their rights to do so. Victim-offender mediation, discussed in Section $B$, is one way to give victims a greater role. Another is to offer opportunities for offenders, with court supervision and victims' consent, to communicate with victims and make restitution before sentencing. A third is to give victims the right to speak with or question offenders at trial or plea hearings and at sentencing. Victims could also have the right to respond to offenders' statements at plea hearings and at sentencing. For example, a robbery victim might challenge the offender's suggestion that his problem with alcohol or drugs forced him to commit a mugging. These challenges might break down denials and evasions, leading to more complete catharsis and closure. Indeed, George Fletcher would go so far as to give victims the right to veto plea bargains and to question prosecution and defense witnesses at trial. ${ }^{274}$ But victims need not be in the driver's seat. Simply giving them the chance to speak and perhaps question will help them to feel respected and heard.

270. Id. at 6, 9-10 (also suggesting that criminal justice officials sometimes view restitution as inappropriate).

271. See Strang \& Sherman, supra note 42 , at 24-25.

272. WEMMERS, supra note $25 \mathrm{l}$, at 208.

273. DAS, supra note 251 , at 123.

274. FLETCHER, supra note 58, at 193-97, 247-50. We do not embrace this proposal. It goes too far toward supplanting punishment by ceding actual control of prosecutorial actions to the victim. This would make punishment less a matter of state-imposed suffering to reaffirm the community's moral norms and more one of private revenge and redress between individuals. $C f$. DUFF, supra note 66 , at 60-64 (contending that crimes are properly understood not simply as wrongs against victims, but also as public wrongs to which the community should respond). 
Of course, not all of this would be appropriate in the presence of juries. In addition, trial judges would need to regulate the time and manner of victim participation to minimize any danger that recalcitrant offenders might further wound their victims. Trial judges are more than capable of doing so, however. Notice and an opportunity to be heard, the fundamental requirements of due process, would empower victims and increase the opportunities for apology and reconciliation.

\section{E. Fixing Plea Procedures}

Right now, guilty plea hearings are often dry recitations of rights and facts. Judges advise defendants of a laundry list of procedural rights they are waiving, and defendants answer "yes" to indicate that they understand each one. ${ }^{275}$ After that, defendants provide very brief factual statements explaining what they $\mathrm{did}^{276}$ which are often written by their lawyers. Defense lawyers may tell their clients to say that they know they did something wrong and are sorry. These perfunctory, scripted statements are far from full apologies. Plea procedures do little else to encourage remorse or apology, particularly because victims and community members are absent.

These plea hearings could do much more than simply recite rights and facts. Judges could use their existing authority to truly judge. They could take the time to observe and evaluate defendants. Defendants often deny or minimize their behavior or offer excuses. ${ }^{277}$ Judges could keep them honest by questioning them closely, probing their excuses, and refusing to accept pleas if defendants denied or evaded guilt. ${ }^{278}$ For example, they could ask questions about defendants' statements during the crime, how victims appeared at the crime, the harm inflicted, and the use of force or weapons. These questions could elicit spontaneous responses from defendants, breaking them away from scripted statements drafted by their lawyers. They would also draw attention to the impact of the crime on the victim and reveal defendants' awareness of and attitudes or indifference toward victims. Judges could probe defendants' explanations for their behavior, their remorse or sorrow, and their willingness to apologize sincerely or grudgingly. For example, a judge could challenge a rapist's insinuation that the victim consented to sex or was asking for sex by flirting or wearing provocative clothing. If victims were present and took part in plea hearings,

275. See, e.g., FED. R. CRIM. P. 11(b)-(c) (requiring judges to advise defendants of a list of rights at guilty plea colloquies).

276. See, e.g., id. 11(b)(3) (requiring a factual basis before a court may accept entry of a guilty plea).

277. See Bibas, supra note 10, at 1393-94.

278. Id. at 1407-08 (proposing restricting or abolishing Alford and nolo contendere pleas). 
as suggested in the previous Section, judges could encourage dialogue between the parties. Judges could encourage victims to describe the crime from their perspectives, compare them with the defendants' versions, and listen to defendants' reactions. Some defendants would deny, hedge, or minimize responsibility; others might be resigned or remorseful; still others would openly apologize. Of course, defendants or victims might refuse to participate. But if they participated, the result might be reconciliation, healing, and closure. Judges might also learn information that would be useful at sentencing, as the next Section discusses. To make sure that sentencing judges have this information, federal courts should end the common practice of farming out guilty plea colloquies to magistrates. ${ }^{279}$ Instead, the judge who will sentence should hear the plea colloquy.

One could imagine going further and empanelling a plea jury. The plea jury could perhaps question defendants (via the judge or prosecutor), probing their statements. The plea jury's main function, however, would be symbolic, representing the community wounded by the crime. ${ }^{280}$ Perhaps the idea of plea juries is too cumbersome to replicate broadly. But for serious violent crimes, where identifiable victims have been badly hurt, the experiment might be worth trying.

\section{F. Sentencing}

The one place where remorse and apology currently appear in the American criminal justice system is at sentencing. At sentencing, defendants sometimes express sorrow and apologize, and victims sometimes air their suffering and forgive. By and large, however, sentencing is not well structured to promote remorse and apology. In theory, a judge can tailor the sentence to reflect a defendant's degree of sincere remorse and repentance. Even the most rigid sentencing scheme (the federal one) gives judges discretion to award standardized sentence discounts for acceptance of responsibility. ${ }^{281}$ In practice, however, most

279. See id. at $1410 \mathrm{n} .246$ (collecting citations to federal cases in which federal district courts referred guilty plea hearings to magistrates).

280. Jason Mazzone has proposed a similar mechanism for a different purpose: plea panels with broad power to investigate the voluntariness and fairness of proposed plea bargains. Jason Mazzone, The Waiver Paradox, 97 Nw. U. L. REv. 801, 874-78 (2003). This searching inquiry would likely be too burdensome to apply broadly, greatly expanding the time and expense required for each plea. Moreover, lay jurors may have neither the ability nor the inclination to second-guess the prosecution's behavior in obtaining pleas. Lay jurors, by contrast, are perfectly suited to represent the wounded community and to seek remorse and apology.

281. U.S. Sentencing Guidelines Manual $\S 3$ El.1 (2003). The Supreme Court is currently considering whether to invalidate the Federal Sentencing Guidelines in United States $v$. Booker, No. 04-104 (U.S. filed July 21, 2004), and United States v. Fanfan, No. 04-105 (U.S. filed July 21, 2004). The Court's decision should not affect our point. Even though the Supreme Court has restricted judges' ability to find aggravating facts unilaterally, it has not questioned 
federal judges award these discounts almost automatically for guilty pleas, no matter how grudgingly the defendant admits guilt or how little remorse he shows. ${ }^{282}$ Likewise, while state sentencing schemes preserve judges' discretion to adjust sentences, judges use their discretion not to reward remorse but to reward efficiency regardless of remorse. Anecdotal studies show that judges reward guilty pleas with sentence discounts not because these offenders are more contrite but because they spare the court's time. ${ }^{283}$

We see arguments both ways on whether and how judges should consider remorse and apology in determining sentences. One argument is that remorse and apology are valuable only as free, unprompted expressions of conscience. Ideally, offenders should apologize for apology's sake rather than out of a mercenary desire to reap lower sentences. Indeed, that is exactly what happened in medieval and colonial times: A criminal would confess, apologize, reconcile with the community, and then hang from the gallows that day or the next. ${ }^{284}$ Commodifying an apology can subvert and cheapen it, watering down its force and encouraging insincere, selfinterested apologies. ${ }^{285}$ Furthermore, it is not easy to measure sincere remorse and apology, as many offenders feign remorse to reap sentence discounts. $^{286}$

On the other hand, these practical objections could just as easily apply to other metrics for punishment. An offender's blameworthiness, need for specific deterrence or incapacitation, and amenability to rehabilitation require careful factfinding. Offenders often falsely portray themselves as less blameworthy, more peaceful, or more virtuous than they are, yet we trust sentencing judges to discern their sincerity and honesty. Blameworthiness, peacefulness, and virtue are not objectively verifiable facts any more than remorse-the practical factfinding problems are no

judges' power to award mitigating adjustments, such as acceptance-of-responsibility discounts. See Blakely v. Washington, 124 S. Ct. 2531, 2537-40 (2004); Apprendi v. New Jersey, 530 U.S. $466,481,490$ n.16 (2000).

282. See supra note 18.

283. See Milton Heumann, Plea Bargaining: The Experiences of Prosecutors, JUDGES, AND DEFENSE ATTORNEYS 134, 144-48 (1978) (noting that judges tend to rubber-stamp plea agreements primarily to promote efficiency and clear their dockets); Albert W. Alschuler, The Changing Plea Bargaining Debate, 69 CAL. L. REV. 652, 661-69 (1981) (explaining that, while a few defendants go to trial because they are defiant or in denial, most pleas are motivated not by remorse but by pragmatic recognition that they earn substantial sentencing discounts).

284. STUART BANNER, THE DEATH PENALTY 16-23, 42 (2002) (describing repentance, confession, and reconciliation as central elements of and justifications for capital punishment around 1700); MICHEL FOUCAULT, DISCIPLINE AND PUNISH: THE BIRTH OF THE PRISON 43, 4950 (Alan Sheridan trans., Vintage Books 2d ed. 1995) (1975) (same, in the 18th century); LAWRENCE M. FRIEDMAN, CRIME AND PUNISHMENT IN AMERICAN HISTORY 26 (1993) ("The condemned were expected to play the role of the penitent sinner; it was best of all if they offered a final confession, a prayer, and affirmed their faith, in the very shadow of the gallows.").

285. See Taft, supra note 14, at 1156-57.

286. See O'Hear, supra note 7, at 1555; see also supra text accompanying note 75 . 
more daunting here. Indeed, anyone who has ever attended a smattering of sentencing hearings is familiar with a variety of behavior: Even when they have an incentive at sentencing to seem remorseful, some offenders remain in denial. Some continue to make excuses for their conduct. Some stiffly read statements written by their lawyers. And some display real emotion and make heartfelt apologies. Judges must gauge sincerity, but this task is similar to trusting judges or juries to determine witnesses' credibility.

The harder objection is the theoretical one. Is an expression of remorse and apology induced by the hope of sentence discounts worthless? We are inclined to think not. Even insincere remorse and apologies may be better than none at all. Such expressions vindicate victims, drive home awareness of wrongs, and may ultimately lead offenders to internalize that awareness. People are reluctant to apologize when they think they are in the right, in part because expressing remorse is a step towards accepting and believing it. ${ }^{287}$ The very act of apologizing teaches, which explains why parents make their children apologize (grudgingly) for hitting a sibling or taking a toy. ${ }^{288}$ In other words, the ordeal of expressing remorse and apologizing, even if done initially for the wrong reasons, may in time promote genuine repentance. ${ }^{289}$ Furthermore, victims may find even half-hearted apologies satisfying, as they vindicate victims and humble offenders. ${ }^{290}$ This explains why victims negotiate for confessions and apologies as part of settlements or plea bargains, even though the apology is an obvious quid pro quo. ${ }^{291}$

287. See Bibas, supra note 10 , at $1399,1399-400$ (" $[E]$ ven feigned or induced repentance may teach lessons to some offenders[, which can] heighten[] the defendant's awareness of the victim's injury, the norm violated, and the community's condemnation. Indeed, the ordeal of feigning repentance, even if initially done for the wrong reasons, can sometimes lead to genuine repentance." (footnote omitted)); Garvey, Punishment as Atonement, supra note 9, at 1850.

288. Bibas, supra note 10, at 1399 n.197 (noting also that cognitive-dissonance theory teaches that persons who speak things that they do not fully believe are inclined to update their attitudes to bring them into harmony with their statements). While a few apologies may be so transparently insincere as to be offensive, or are immediately repudiated, most vindicate the victim and repudiate the wrong done and thus do some good.

289. Id. at 1399-400.

290. See DUFF, supra note 66 , at $94-95$ (noting that "an apology whose sincerity is doubtful or unknown can still have value," that "apologies can have a ritual or formalized character," and that "between strangers it might be enough that the apology is made-that the ritual is undertaken").

291. See, e.g., Bibas, supra note 10, at 1407 n.234 (reporting cases in which victim or victim's family insisted on an admission of guilt as a condition of a plea bargain); Taft, supra note 14, at 1146; Alan Bemstein, Coleman Fined, Issues Apology in Assault Case, HousTON CHRON., Oct. 11, 2001, at A33 (reporting that victim of a shoving incident "approved Wednesday's plea bargaining because it included an apology," according to the prosecutor); William Brand, $S L A$ Members Face 6-8 Years in Prison; '1970s Revolutionary Group' Pleads Guilty to 2nd-Degree Murder in 27-Year-Old Slaying, OAKLAND (Cal.) TRIB., Nov. 8, 2002, available at LEXIS, News, All (English, Full Text) (reporting that a murder victim's family had agreed to a plea bargain on condition that the four defendants apologize in court, and noting that the four did apologize to the victim's family at sentencing). 
Earlier, we criticized the status quo's use of remorse and apology at sentencing as proxies for the need for deterrence and retribution. We argued that remorse and apology are poor proxies for future dangerousness and blameworthiness and that sentence discounts may undermine general deterrence. ${ }^{292}$ While deterrence and retribution are legitimate guideposts for sentencing, they do not exhaust the roles of remorse and apology. The other benefits of remorse and apology still justify taking them into account at sentencing, even if there is some tradeoff of general deterrence and little impact on specific deterrence and retribution. Moreover, our criticism of deterrence centered on the narrow, classical view of deterrence as making the expected pain of punishment exceed the pleasure of the crime. ${ }^{293}$ Apology and remorse fit much more comfortably with a social-meaning approach to deterrence, such as Kahan's. By reinforcing the social norms violated and morally condemning crimes, apology and remorse may teach moral values and discourage crime in the long run. ${ }^{294}$

If remorse and apology should carry weight at sentencing, courts need more flexibility and information to consider healing as an adjunct to punishment. First, they need flexibility to adjust plea discounts instead of having to apply one-size-fits-all rewards for guilty pleas. Even under longstanding federal law, courts could give the lowest sentences to offenders who make unqualified apologies. In contrast, they could impose full sentences on those who do not apologize at all or who make excuses and award partial reductions for those in between. To make these decisions intelligently, the judge who imposes sentence should be the same one who heard the trial or plea and should have the transcript of any victim-offender mediation sessions.

One could even imagine having sentencing juries, at least in serious violent cases, to represent the conscience of the wounded community. This approach dovetails with the Supreme Court's decision that juries rather than judges must find defendants eligible for the death penalty. ${ }^{295}$ Time and money constraints, however, would probably limit sentencing juries to serious violent crimes, where the need for them might be greatest. ${ }^{296}$

292. See supra Section II.A.

293. The classic exponent of this position is Jeremy Bentham. See BENTHAM, supra note 79, at 170 \& n.1.

294. See Kahan, supra note 9, at 603-04 (noting that Kahan's expressive theory of punishment can reinforce deterrence by shaping people's preferences through moral education).

295. Ring v. Arizona, 536 U.S. 584 (2002).

296. See supra text accompanying note 280. But cf. supra note 55 (collecting law review articles that propose jury sentencing).

The Supreme Court's recent decisions have mandated some role for jury fact-finding in determinate sentencing. See Blakely v. Washington, 124 S. Ct. 2531 (2004); Apprendi v. New Jersey, 530 U.S. 466 (2000). In practice, however, legislatures and prosecutors are likely to circumvent juries through plea bargaining, redrafted sentencing guidelines, and more mandatory 
The process should not end at sentencing. As Section II.C notes, Wisconsin, lowa, and Minnesota encourage victim-offender mediation in prison. After living with the burden of their guilt, offenders who persist in denial may apologize later. While we have been unable to find quantitative data on the success of these programs, they appear promising. Scholars should investigate further, and policymakers should consider replicating them on a larger scale.

\section{G. Costs and Difficulties of Implementing Remorse and Apology}

A few caveats are in order. We recognize that remorse and apology will not always work. Some offenders will remain defiant. Some suffer from psychopathy, which impairs the capacity to empathize and so feel remorse. ${ }^{297}$ Some victims will be rationally or irrationally fearful of meeting with their offenders and reliving the trauma. And some-although surprisingly few ${ }^{298}$ - may care little about such expressions and may want only vengeance. Remorse and apology are harder to orchestrate for socalled victimless crimes, such as low-level drug possession crimes, tax evasion, or perjury. So, too, certain inchoate crimes, such as conspiracy,

minimum sentences, and many states still use discretionary sentencing. See supra text accompanying notes 281-283. Thus, juries are unlikely to play a major role in most cases. See Stephanos Bibas, Blakely's Federal Aftermath, 16 FED. SENTENCING REP. 333, 338-39 (2004).

After sentencing, one might also consider time limits on the civil disabilities that confront convicted felons, such as disenfranchisement. Some felons, those guilty of the most serious felonies, may face death or life imprisonment. But most will reenter society, and society must consider when to reintegrate and reconcile with them, to symbolically encourage healing and redemption. Perhaps those who demonstrate remorse and apologize show their willingness to turn over a new leaf, and their civil disabilities should end at some point after their parole or probation ends. See generally Brian C. Kalt, The Exclusion of Felons from Jury Service, 53 AM. U. L. REV. 65,67 nn.4-5 (2003) (discussing service by felons on juries and collecting citations to articles discussing disenfranchisement of felons).

297. For general treatments of psychopathy and how it impairs the conscience and the capacity to empathize and feel remorse, see generally HERVEY CLECKLEY, THE MASK OF SANITY: AN ATTEMPT TO REINTERPRET THE SO-CALLED PSYCHOPATHIC PERSONALITY 239-47 (1941); and Robert D. HaRe, Without Conscience: The Disturbing World of the PSYCHOPATHS AMONG US 40-46 (1999). Psychopaths may be able to feign remorse to manipulate the system to gain lenient treatment. See, e.g., Dave Cullen, The Depressive and the Psychopath: At Last We Know Why the Columbine Killers Did It, SLATE, Apr. 20, 2004, http://slate.msn.com/id/2099203/ (explaining that Columbine school shooters Eric Harris, who was a psychopath, and Dylan Klebold feigned remorse as part of a diversion program for an earlier property crime).

298. See Strang \& Sherman, supra note 42 , at 18 ("While individual victims may be angry and initially seek vengeance, surveys have repeatedly found that most victims do not have these feelings."). An individual victim's potential vengeful inclinations, of course, are a concern for any proposal that gives victims a role in the criminal process, not just ours. In light of the small percentage of victims who harbor these feelings and the proposed supervision of victims' and offenders' participation, this possibility presents little cause for alarm. 
often do not concretely harm any readily identifiable victims. ${ }^{299}$ It may be possible, however, to treat affected community residents as victims, as many so-called victimless or inchoate crimes have palpable effects on neighborhoods and communities. ${ }^{300}$ Like victimless crimes, other crimes will have a diffuse impact on a large group of people, as when a corporation recklessly poisons a neighborhood creek. Demands for corporate apologies are becoming quite prevalent, and the desire for apologies confirms apology's power even for less discrete crimes. ${ }^{301}$ Evidently, apology is powerful and desirable even if it must be addressed to a broad audience or to a representative sample of all victims. For example, a corporate embezzler could apologize in person to a sample of corporate employees and shareholders and include a written apology in the company's annual report.

Remorse and apology may vary depending on the cultural context and social fabric. In some neighborhoods, the social fabric may be weaker and so harder to mend. Some offenders, such as aliens who are to be deported, cannot be reintegrated into society. Some offenders' and victims' relationships are nonexistent or badly frayed and difficult to repair. Remorse and apology can nonetheless vindicate victims, teach them that the crimes were not their fault, and heal both victims and offenders. Remorse and apology may be most powerful in small, close-knit communities and homogeneous cultures. ${ }^{302}$ But even in large, heterogeneous communities, remorse and apology still hold some power; in large American cities people also care about their relationships and reputations. ${ }^{303}$

Moreover, encouraging remorse and apology takes time and money. More time and money spent here means less elsewhere, with fewer crimes

299. This is by no means true for all inchoate crimes. Attempted murders, attempted muggings, attempted burglaries, and the like all cause at least psychological (if not physical or monetary) harm to easily ascertainable victims. Victims of such attempts, like victims of completed crimes, will be proper objects of remorse and apology for both their own and their offenders' sakes. See, e.g., supra note 185 and accompanying text (noting example of a successful mediation session between an attempted murderer and his victim).

300. See, e.g., DUFF, supra note 66, at 113 (noting that for crimes that injure the community, the offender owes the wider community "an apology that recognizes the nature and seriousness of the wrong done"); id. at 162 ("[Where] there is no individual victim who could take part in the [criminal mediation] process ... the negotiation must be between the offender and the community as a whole ....").

301. See, e.g., Lisa Bannon, Slave-Labor Suit Targets Japanese Firms; Case Alleges That Mitsui and Mitsubishi Abused Chinese in World War II, WALL ST. J., Aug. 23, 2000, at A18; Martin J. Moylan, Travel Group Presses Northwest for Apology, DULUTH (Minn.) NEWS-TRIB., Jan. 20, 2004, available at 2004 WL 56722804.

302. See Massaro, supra note 68 , at 1916-17.

303. See DuFF, supra note 66, at 93 (noting that, even where victim and offender are not directly or previously related, "[r] citizenship, of mutual respect and concern, that the crime damaged"); Whitman, supra note 193, at 1068, 1064-68 (arguing that shaming sanctions are "likely to work . . . even in a modern, western, urban society," because they will still "have a real psychic impact"). 
and defendants investigated, prosecuted, and convicted. Giving a meaningful role to offenders, victims, and communities means loosening the control of prosecutors and defense lawyers. These are real costs, but the value of remorse and apology may well outweigh them. At the very least, we should begin to discuss when these costs are worthwhile.

Other critics will object that remorse and apology seem like communitarian impositions of morality in our libertarian political culture. While it is important as a rule to respect citizens' freedom of conscience, offenders have proven by their criminal acts that they do not respect victims' rights. The criminal justice system already tries to teach them lessons, whether through a crude cost-benefit deterrence calculus or through rehabilitation. Encouraging offenders to learn the value of the rights they have violated by asking them to acknowledge and repudiate their crimes hardly seems a totalitarian invasion of conscience. This is particularly true because the lesson taught is limited to that narrow set of acts that society has defined as crimes. Offenders and victims, moreover, are always free to refuse to participate.

Of course apology will not be a panacea, and of course there will be practical problems, such as divining sincerity and coaxing offenders and victims to meet. Including the community will also take some work; news articles could publicize apologies to the affected community, and community representatives could attend court proceedings. Lawyers who are used to litigation will take some time to warm up to mediation, just as they have done in the civil context. Once sentencing benefits, evidentiary privileges, and procedural reforms encourage this mediation, lawyers may slowly learn how to benefit their clients by using these new tools. Properly done, remorse and apology can supplement our traditional adversary criminal process without supplanting its procedures, rights, and duties.

\section{CONCLUSION}

Lawyers, schooled in law and economics, are taught to evaluate settlements from a rational-actor perspective. We add up the monetary benefits, subtract the monetary costs, and arrive at a net present value. Of course, monetary costs and benefits matter a great deal, and consequentialism is certainly relevant. But the ordinary person does not evaluate crime and punishment that way. ${ }^{304}$ Blame, status, and expressive concerns matter to the ordinary person, and crime estranges offenders from

304. Cf. Russell Korobkin \& Chris Guthrie, Psychology, Economics, and Settlement: A New Look at the Role of the Lawyer, 76 TEX. L. REV. 77, 96-101, 121-22 (1997) (finding that lawyers are less susceptible to framing effects than nonlawyers and attributing this difference to lawyers' training in measuring the expected economic value of various options). 
victims and society. Criminal punishment is one essential part of balancing the scales of justice, but it is not the only part. Offenders should also realize the wrongfulness of their acts, feel sorrow for their misdeeds, and accept responsibility. If offenders can express remorse to victims and ask their forgiveness, they humble themselves and thereby come clean. This humility teaches offenders valuable moral lessons. If encouraged in the right way, remorse and apology can help offenders cleanse their consciences and return to the moral fold. It can also touch victims, allowing them to achieve catharsis, let go of their anger, and forgive.

More generally, criminal procedure can broaden its horizons beyond the narrow procedural values of efficiency, accuracy, and procedural fairness. It can take account of the social and relational dimensions of criminal wrongdoing. Substantive values such as moral education, catharsis, healing, and reconciliation should inform procedural choices. In the case of remorse and apology, about which the criminal law cares deeply, procedure can and should make more room for the substantive values that these expressions serve. Victims should have more opportunities for face-to-face, dyadic interaction with offenders, especially through mediation and similar mechanisms. Prosecutors and defense counsel should warm to the social and psychological benefits of remorse and apology. They should encourage and use these expressions throughout the criminal process, from informal resolution early on to more effective plea agreements to better use of cooperating witnesses at trial. Plea and sentencing procedures themselves should look beyond the offender's individual badness. They should take greater account of the social, psychological, and relational aspects of crime by making room for remorse and apology and involving victims and community members. Procedure, in short, should serve substance instead of ignoring its goals.

Remorse and apology are fundamentally moral, and the law cannot force them. Offenders and victims enjoy freedom of conscience, and they have the right to remain defiant. But the law can remove roadblocks to remorse, provide opportunities and venues, and encourage offenders and victims to speak face to face. Prosecutors, defense counsel, and judges can all come to see themselves as players in a human moral drama and not simply as assembly-line processors of fungible, criminally disposed individuals. Perhaps this vision is idealistic, but the examples of civil and victim-offender mediation show that reality can pursue the ideal in at least some cases. The criminal justice system should aspire to these ideals even if it cannot implement them overnight. 